\title{
Apolipoprotein A-I (ApoA-I), Immunity, Inflammation and Cancer
}

\author{
Konstantina Georgila ${ }^{1,2, \dagger}$, Dimitra Vyrla ${ }^{1,2, \dagger}$ and Elias Drakos ${ }^{2, *}$ \\ 1 Department of Biology, Medical School, University of Crete, Heraklion, Voutes, 71110 Crete, Greece \\ 2 Department of Pathology, Medical School, University of Crete, Heraklion, Voutes, 71110 Crete, Greece \\ * Correspondence: drakil@uoc.gr; Tel.: +30-2810394708 \\ + These authors contributed equally to this work.
}

Received: 20 June 2019; Accepted: 30 July 2019; Published: 1 August 2019

\begin{abstract}
Apolipoprotein A-I (ApoA-I), the major protein component of high-density lipoproteins (HDL) is a multifunctional protein, involved in cholesterol traffic and inflammatory and immune response regulation. Many studies revealing alterations of ApoA-I during the development and progression of various types of cancer suggest that serum ApoA-I levels may represent a useful biomarker contributing to better estimation of cancer risk, early cancer diagnosis, follow up, and prognosis stratification of cancer patients. In addition, recent in vitro and animal studies disclose a more direct, tumor suppressive role of ApoA-I in cancer pathogenesis, which involves anti-inflammatory and immune-modulatory mechanisms. Herein, we review recent epidemiologic, clinicopathologic, and mechanistic studies investigating the role of ApoA-I in cancer biology, which suggest that enhancing the tumor suppressive activity of ApoA-I may contribute to better cancer prevention and treatment.
\end{abstract}

Keywords: apolipoprotein A-I; HDL; cancer; immunity; inflammation; review

\section{Introduction}

Apolipoprotein A-I (ApoA-I), the major protein component of high density lipoprotein (HDL), widely known for regulating cholesterol trafficking and for protecting against cardiovascular disease (CVD), may also modulate inflammatory and immune responses [1]. Recent studies suggest that organismal metabolic changes that include shifts in the levels and the quality of ApoA-I, may facilitate cancer initiation and progression [2,3]. Herein, we present and review the findings of various epidemiologic, clinicopathologic, and mechanistic studies implicating ApoA-I in cancer, with emphasis on its connection with inflammatory and immune-modulating effects.

The ApoA1 gene is regarded to have the same evolutionary origin with the genes of apolipoproteins A-II, A-IV, C-I, C-III, and E, by virtue of duplication and diversification of a basic genetic motif encoding an $11 / 22$ amino acid sequence with a characteristic $\alpha$-amphipathic helix signature [4-7]. Homologous ApoA-I-encoding genes have been described in mammals, birds, and teleost fish [8].

The regulation of human ApoA1 gene expression is complex and is controlled at multiple levels. The transcription of human ApoA1 largely depends on two hormone response elements (HREs) proximal to the transcription start site that bind members of the hormone nuclear receptor superfamily. Among them, peroxisome proliferator-activated receptor- $\gamma$ (PPAR $\gamma)$ appears to have a prominent role in ApoA1 transactivation by interacting with HREs as heterodimer with RXR $\alpha$. Other transcription factors implicated in the regulation of ApoA1 promoter include the hepatocyte nuclear factor 4 (HNF4), Liver Receptor Homologue 1 (LRH1) and the ApoA-I Regulatory Protein 1 (ARP1/NR2F2) which activate and repress the ApoA1 promoter, respectively [9]. HNF4 operates together with Sp1 in the 
communication of $A p o A 1$ promoter with enhancer sequences that facilitate the recruitment of the basal transcriptional machinery.

ApoA-I expression is also controlled by a long noncoding RNA, ApoA1-AS, which is transcribed in the apolipoprotein gene cluster on chromosome 11q23.3 and modulates suppressive epigenetic marks leading to ApoA1 transcriptional repression [10]. Interestingly, the liver, small intestine, and colon where ApoA-I is predominantly detected, show approximately 100-fold higher expression levels of ApoA1 mRNA compared to ApoA1-AS, whereas the ApoA1/ApoA1-AS ratios are less than one in most other tissues [10]. Post-transcriptional mechanisms may also contribute to the regulation of ApoA-I expression in certain conditions. Thus, an enrichment of polysomal fractions with ApoA1 mRNAs explains the increase in ApoA-I synthesis observed in high fat-fed mice in the absence of an effect on transcription [11].

Following translation and intracellular removal of a N-terminal signal peptide, ApoA-I is secreted as a lipid-poor/free mature protein of 243 amino acids and a molecular weight of approximately $28 \mathrm{kDa}$ [6]. Its structure contains ten consecutive helical regions, critical for the biophysical properties of the protein to spontaneously solubilize lipids in aqueous environment [6]. Based, exactly, on the properties of these amphipathic helical motifs, various peptides, without sharing any sequence homology, have been synthesized, known as ApoA-I mimetics, because of their ability to simulate ApoA-I functionality [12-14]. In physiological conditions, the bulk of ApoA-I constitutes approximately $70 \%$ of the protein component of HDL, which are microemulsions composed of a nonpolar lipid core, a surface polar lipid monolayer and up to 95 different proteins $[15,16]$.

HDL are heterogeneous and dynamic structures exchanging lipids with cells and other lipoproteins, classified to different subcategories with pre- $\beta 1$ HDL corresponding to lipid-poor ApoA-I $[17,18]$. ApoA-I is essential for the assembly of HDL. ApoA-I stabilizes the ATP-binding cassette transporter 1 (ABCA1), a member of the ABC superfamily, at the cell membrane of hepatocytes and enterocytes, enabling it to mediate the efflux of cellular phospholipids and free cholesterol to nascent discoid HDL particles harboring two to four molecules of ApoA-I, leading to the biogenesis of HDL particles. A similar lipid efflux by ABCA1 in cells of peripheral tissues initiates the reverse cholesterol transport (RCT) $[17,19]$ (Figure 1). Also, ApoA-I activates lecithin cholesterol acyl transferase (LCAT), leading to the maturation of HDL particles [20]. Interaction of lipidated ApoA-I in discoid or more mature HDL particles with another transporter of the ABC family, ATP-binding cassette subfamily G member 1 (ABCG1), contributes further to the RCT [21]. HDL particles undergo additional remodeling through interaction with the cholesteryl ester transfer protein (CETP) [22]. Finally, binding of HDL particles to the scavenger receptor class B type 1 (SR-BI), transfers cholesterol down a cholesterol gradient $[23,24]$. As a result, cholesterol mobilized at peripheral tissues can enter the liver and is catabolized and excreted to the bile [24-26]. ApoA-I itself is mainly catabolized in the liver [27,28] (Figure 1).

Besides promoting RCT, ApoA-I inhibits apoptosis and pro-oxidative and proinflammatory processes in endothelial cells, induces vasodilation, inhibits the activation of platelets, and contributes to innate immunity. Some of these functions are relevant to inflammatory and malignant processes and are discussed below. 


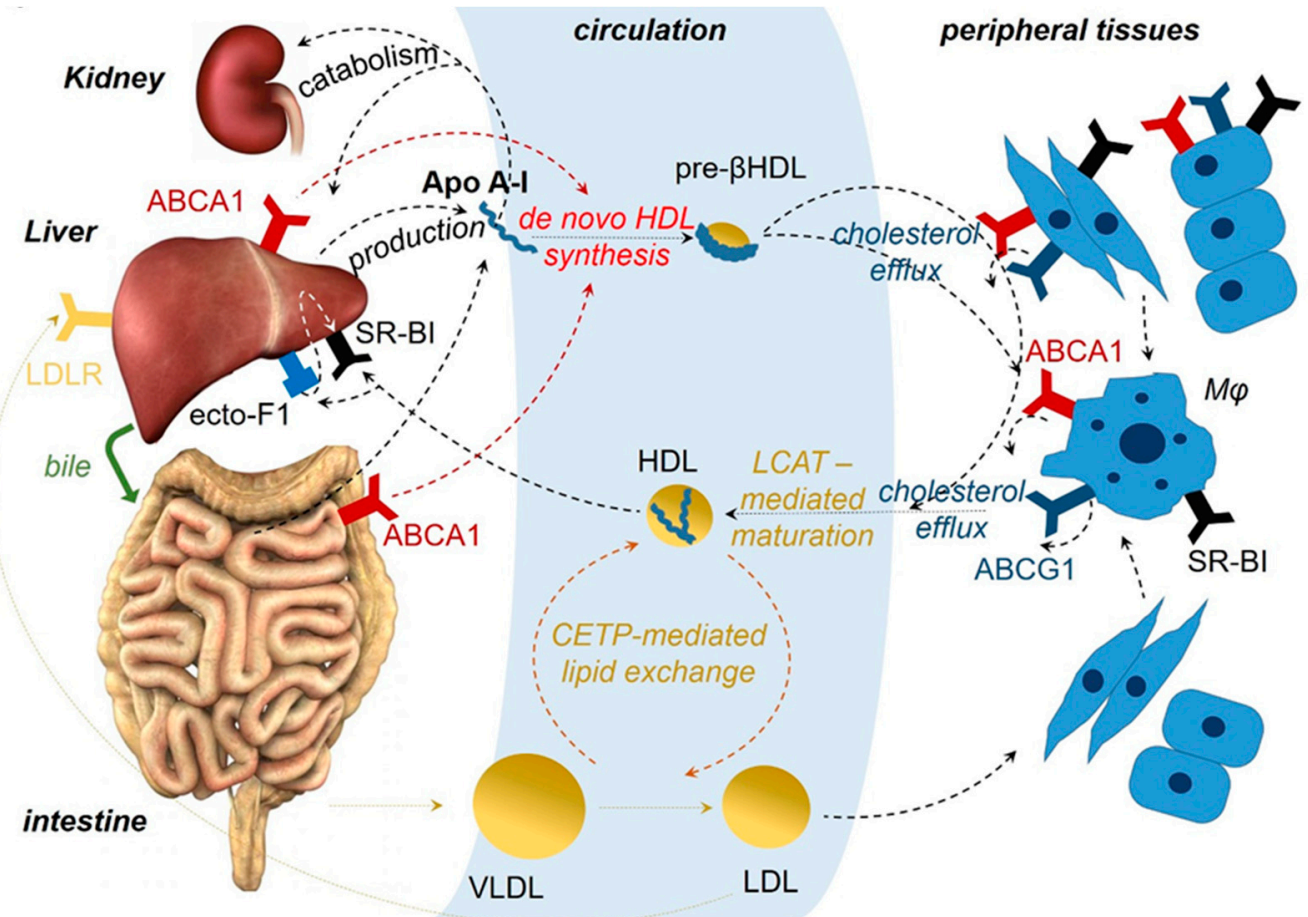

Figure 1. ApoA-I in relation to high-density lipoprotein (HDL) biogenesis and reverse cholesterol transport (RCT). About $75 \%$ of the ApoA-I protein is produced by hepatocytes and the remaining $25 \%$ by epithelial cells of the small intestine. It has been shown that some ApoA-I is also produced by the most proximal part of the mouse colon, in line with the reported ApoA-I expression in human fetal colon. ApoA-I is mainly catabolized in the liver. In addition, ApoA-I protein unassociated with lipids can be filtered in renal glomeruli, recognized by cubulin, a protein synthesized by distal renal tubular cells, internalized and degraded by renal epithelial cells. Binding of ApoA-I to ABCA1 at the cell membrane of hepatocytes and enterocytes mediates the production of nascent HDL particles. A similar efflux of lipids by ABCA1 and ABCG1 directly in various cells, or indirectly in macrophages $(\mathrm{M} \varphi)$ of peripheral tissues, contributes to the RCT. LCAT, which catalyzes the esterification of free cholesterol and interaction through CETP transferring cholesterol esters to very low density lipoproteins (VLDL) and low density lipoproteins (LDL) and the phospholipid transfer protein (PLTP) transferring phospholipids from VLDL lipoproteins to HDL, leads to maturation and remodeling of HDL particles. Binding of HDL particles to SR-BI, expressed in hepatocytes, transfers cholesterol esters and other lipids, so that excess cholesterol can be accepted by the liver, catabolized, and excreted via the bile to the intestine. Also, binding of HDL remnants produced after the action of endothelial lipase, or lipid-poor ApoA-I to the beta chain of ATP F1 synthase, expressed at the cell membrane of hepatocytes and other cells (called, also, ecto-F1F0-ATPase that is similar to the F1F0 inner mitochondrial membrane protein complex) promotes cell internalization of HDL particles bound to SR-BI. Abbreviations for various receptors and enzymes are explained in the main text.

\section{ApoA-I, Immunity, and Inflammation}

Throughout its evolutionary course, ApoA-I/HDL contributes to the humoral part of innate immunity [29]. It has antiviral activity associated with prevention of viral penetration, facilitation of complement-mediating bacterial killing, and protection against trypanosome brucei, a protozoal parasite [30-32]. ApoA-I protects from sepsis by binding to and neutralizing lipopolysaccharide (LPS) and lipoteichoic acid (LTA), components of the Gram-negative and Gram-positive bacterial cell wall, respectively [33,34]. Clearance of LPS through binding of HDL-LPS to SR-BI results in lower activation of the Toll-like receptor 4 (TLR4), the corresponding pathogen-associated molecular pattern (PAMP) recognition receptor, and in decreased production of tumor necrosis factor (TNF), interleukin $1 \beta$ (IL-1 $\beta$ ) and interleukin 6 (IL-6) by the proinflammatory cells that mediate sepsis pathology $[29,35,36]$. In line 
with these experimental findings, reduced serum ApoA-I levels in sepsis patients are associated with poor prognosis $[37,38]$. Also, ApoA-I was found to increase the levels of pentraxin 3 (PTX3), an acute phase protein, which recognizes PAMPs in viruses, bacteria, and fungi [39,40].

Inflammatory cytokines such as TNF and IL-1 $\beta$ repress the production of ApoA-I from hepatocytes and increase the expression of serum amyloid A (SAA), which becomes the major protein component of HDL in this context [41-43]. Consequently, lipid-poor ApoA-I is rapidly catabolized in the liver and the kidney. These findings could be meaningful if ApoA-I, in addition to its proimmune features, had anti-inflammatory potential. In this way, removal of ApoA-I could intensify the inflammatory response, resulting in a more robust effect. On the other hand, decreased levels of ApoA-I could contribute to destructive chronic inflammation characterizing many autoinflammatory and autoimmune diseases. Indeed, a plethora of studies have shown that ApoA-I exhibits anti-inflammatory features by various mechanisms [1]. In the context of the humoral arm of innate immunity, it has been shown that ApoA-I inhibit the formation of the terminal attack complex of the complement, C5b-9, by interfering with $\mathrm{C} 9$ polymerization and incorporation into the membrane and contributes to complement clearance [44]. Also, ApoA-I-mediated increase of PTX3 levels could contribute to a better healing, given that PTX3 can promote efficient tissue repair [45].

In a seminal study, it was shown that mice deficient for the receptors Abca1 and Abcg1 display marked leukocytosis and a transplantable myeloproliferative disease, which can be suppressed by transgenic overexpression of ApoA-I [46]. These findings suggest an inhibitory role of ApoA-I in cellular components of the immune system which has been postulated to relate to the lipid-modulating function of ApoA-I. One potential mechanism involves modulation of cholesterol-enriched lipid raft microdomains that function as docking sites for several receptors, coreceptors, and costimulatory molecules in neutrophils, monocytes/macrophages, dendritic cells (DC), and B and T lymphocytes [47-49]. ApoA-I, via ABCA1, reduces the abundance of lipid rafts and lowers the levels of CD11b expression leading to downregulation of neutrophil activation, migration, and adhesion [50]. A similar mechanism has been proposed for downregulation of TLR signaling in macrophages and major histocompatibility (MHC) class II molecule expression in antigen presenting cells with consequent attenuation of adaptive immune responses [51]. Inhibition of dendritic cell maturation and differentiation by ApoA-I is associated with elevated secretion of prostaglandin E2 (PGE2) and IL-10 and downregulation of IL-12 and IFN- $\gamma$ [52]. Similarly, inhibition of dendritic cell maturation and downregulation of Th1 and Th17 cell reactivity by ApoA-I/HDL leads to attenuation of arthritis in an antigen-induced murine arthritis model [53].

In contrast, a recent study provided evidence that the ability of ApoA-I/HDL to suppress the TLR-mediated secretion of proinflammatory cytokines IL- 6 and TNF in monocytes was dependent on transcriptional events mediated by the induction of activating transcription factor 3 (ATF3) and independent of TLR signaling and cholesterol modulation in lipid rafts, implying "outside-in" signaling events induced by ApoA-I/HDL that remain obscure [54]. Another anti-inflammatory mechanism was recently proposed. It was observed that ApoA-I/HDL decreased the expression of inflammasome components, including NLR family pyrin domain containing 3 (NLRP3) and IL-1 $\beta$, as well as caspase 1 activation in human macrophages [55]. In addition, by using a murine model of atherosclerosis, it was shown that myeloid Abca1/g1 deficiency enhanced caspase-1 activation in monocytes, macrophages, and neutrophils, resulting in enhanced atherogenesis that was suppressed by Nlrp3 or Caspase-1/11 deficiency $[56,57]$. Also, the link between ApoA-I/HDL and inflammasome activation in dendritic cells and has been recently reported in a systemic lupus erythematosus-like murine model [58]. These findings suggested that accumulation of cholesterol in macrophages, or dendritic cells acting as a "danger signal", could activate the inflammasome leading to chronic inflammation, something that can be opposed by ApoA-I/HDL.

Additional effects on specific cellular compartments of the immune system by ApoA-I have been discovered. Thus, administration of ApoA-I suppressed inflammation in autoimmune-prone mice lacking both LDL-receptor and ApoA-I, an effect that was associated with expansion of regulatory 
$\mathrm{T}$ cells (Treg) and a decrease of effector/effector memory T cells [59]. Another study showed that ApoA-I and ABCA1 play a pivotal role in the extracellular release of isopentenyl pyrophosphate and the consequent activation of $\mathrm{V} \gamma 9 \mathrm{~V} \delta 2 \mathrm{~T}$ cells, a specialized type of lymphocytes that recognize phosphor-antigens in a TCR-dependent but MCH-independent manner [60].

Deregulated immunity against microorganisms and pathogenic chronic inflammation can be viewed as different aspects of the same process. A recent study showed that mice deficient in ApoA-I exhibit exaggerated colitis, while administration of an ApoA-I mimetic peptide attenuated gut inflammation, which was associated with decreased secretion of IL-6 by epithelial enterocytes in response to LPS, abundant in the gut lumen [61]. In agreement with these findings, another study reported that the intensified chemically-induced colitis observed in the setting of selective deletion of transcription factor EB ( $\mathrm{Tfeb}$ ) in the murine intestinal epithelium was associated with reduced ApoA-I expression [62]. It has been suggested that part of the anti-inflammatory properties of ApoA-I/HDL may be due to its contribution to innate immunity mechanisms including its ability to neutralize bacterial products [61]. Given that chronic inflammatory conditions may predispose to various types of malignancy, the anti-inflammatory effects of ApoA-I may impinge on cancer-related processes as discussed below in Section 6 .

It must be added that the anti-inflammatory properties of ApoA-I depend not only on the levels of the protein but also on its functionality [63-65]. Many epigenetic alterations of ApoA-I, including oxidative modifications, observed in chronic inflammation may erase its anti-inflammatory features or even transform it to a proinflammatory agent [66].

\section{A Potential Protective Role of ApoA-I against Cancer: Evidence by Association}

Accumulating evidence suggests that regulation of the ApoA-I/HDL axis is derailed in cancer. Our mining of transcriptome microarray data registered in the Oncomine database (https://www. oncomine.org) and of recently published RNAseq data [67] uncovers reduced ApoA1 mRNA levels in hepatocellular carcinoma (HCC) compared to normal liver tissue, the main source of ApoA-I. The transcriptional repression of ApoA1 in HCC remains mechanistically unexplored but it in ine with the reported reduction in protein levels of ApoA-I in both cancerous liver tissue [68] and in the serum of HCC patients [69,70]. HDL itself is also reduced in HCC [71]. Collectively, the reduction in ApoA1 transcription, intracellular and secreted ApoA-I, and circulating HDL levels in HCC hint to a putative tumor suppressor role of this pathway. Indeed, numerous studies have discovered associations between the levels of serum ApoA-I/HDL and various parameters of the natural history of many types of cancer (summarily presented in Table 1).

The Alpha-Tocopherol, Beta-Carotene (ATBC) cancer prevention study showed inverse association between HDL-associated cholesterol (HDL-c) levels and the risk for the development of lung, liver, and hematologic malignancies [72]. The Women's Health Study investigating the cancer risk in female health workers, found that lower levels of HDL were associated with higher risk for the development of lung and colorectal cancer [73]. The Malmo Diet and Cancer Study revealed an inverse association between the risk for the development of colorectal, lung, and breast cancer and the levels of HDL-c and ApoA-I [74]. The correlation between lower levels of HDL/ApoA-I and higher risk for colorectal cancer was also reported in a Korean cross-sectional study, while premalignant lesions of colorectal cancer (colon adenomas) were shown to be associated with lower HDL levels in a cohort of patients examined by colonoscopy [75,76]. Similar associations have been reported for prostate cancer by a Swedish cohort study and for Hodgkin and non-Hodgkin lymphoma by the Cancer Research Network lymphoma study $[77,78]$. The latter found that the more pronounced drop in HDL levels was observed 3-4 years prior to lymphoma diagnosis [77]. 
Table 1. Clinicopathologic associations of Apo A-I in cancer.

\begin{tabular}{|c|c|c|c|c|c|c|}
\hline \multirow[b]{2}{*}{ Orgar } & \multirow[b]{2}{*}{$\begin{array}{l}\text { Type of } \\
\text { Cancer }\end{array}$} & \multicolumn{4}{|c|}{ Association of ApoA-I Levels with: } & \multirow[b]{2}{*}{ References } \\
\hline & & $\begin{array}{l}\text { Risk for the } \\
\text { Development } \\
\text { of Cancer }\end{array}$ & $\begin{array}{c}\text { Cancer at } \\
\text { Primary } \\
\text { Diagnosis }\end{array}$ & $\begin{array}{c}\text { Cancer } \\
\text { Progression/ } \\
\text { Metastasis }\end{array}$ & $\begin{array}{l}\text { Cancer } \\
\text { Prognosis }\end{array}$ & \\
\hline \multirow[b]{2}{*}{ head \& neck } & squamous cell cancer & & & + & & [79] \\
\hline & $\begin{array}{l}\text { nasopharyngeal } \\
\text { carcinoma }\end{array}$ & & & - & - & [80-82] \\
\hline lung & non-small cell carcinoma & - & - & $-(+)$ & - & {$[74,83-87]$} \\
\hline esophagus & squamous cell carcinoma & & - & & - & {$[88,89]$} \\
\hline stomach & gastric cancer & & $-(+)$ & & & {$[90,91]$} \\
\hline colon & adenocarcinoma & - & - & $-(+)$ & - & {$[76,92-97]$} \\
\hline liver & hepatocellular carcinoma & & - & - & - & $\begin{array}{l}{[69,70,98-102]} \\
{[69,70,98-102]}\end{array}$ \\
\hline gallbladder & adenocarcinoma & & - & & & [103] \\
\hline pancreas & adenocarcinoma & & - & & & {$[104,105]$} \\
\hline breast & adenocarcinoma & $-(+)$ & - & - & - & [106-116] \\
\hline ovary & ovarian carcinoma & & - & & - & [117-122] \\
\hline uterus & endometrial carcinoma & & - & & & [123-125] \\
\hline cervix & $\begin{array}{l}\text { cervical squamous cell } \\
\text { carcinoma }\end{array}$ & & - & - & & {$[126,127]$} \\
\hline prostate & adenocarcinoma & - & - & & & {$[78,128,129]$} \\
\hline bladder & $\begin{array}{l}\text { transitional cell } \\
\text { carcinoma, }\end{array}$ & & $-(+)$ & - & - & [130-133] \\
\hline kidney & renal cell carcinoma & & & & - & {$[134,135]$} \\
\hline $\begin{array}{l}\text { hematopoietic/ } \\
\text { lymphoid } \\
\text { system }\end{array}$ & leukemia/lymphoma & - & - & - & & {$[77,136,137]$} \\
\hline \multirow{2}{*}{ neural tumors } & neuroblastoma & & - & & - & [138] \\
\hline & retinoblastoma & + & & & & [139] \\
\hline
\end{tabular}

In line with these risk association studies, reduced serum levels of HDL/ApoA-I have been reported in cancer patients at first diagnosis, indicating that HDL/ApoA-I may be a potential biomarker for early cancer detection. A study analyzing serum lipid profiles of patients diagnosed with any type of solid tumor and healthy controls showed decreased HDL/ApoA-I levels, specifically, in the cancer group [140]. Similarly, relatively decreased levels of HDL/ApoA-I have been reported in many cancers of the gastrointestinal tract including adenocarcinomas of the stomach, the colon, the pancreas, and hepatocellular carcinoma (HCC) $[70,76,83,92-94,98,104,105]$. A serum proteomic analysis of patients with chronic liver disease associated with hepatitis $C$ virus (HCV) infection showed that the development of HCC was associated with lower levels of ApoA-I [69]. Also, relatively reduced serum HDL/ApoA-I levels have been found in patients with lung and breast adenocarcinoma, early stage ovarian and cervical cancer, and acute lymphoblastic leukemia [84,106,117-120,126,136].

The levels of HDL/ApoA-I have also been associated with the progression of the neoplastic disease and the response to therapy. Reduced serum ApoA-I levels correlate with the progression of lung, liver, breast, kidney, endometrial, and cervical cancer, associated with the appearance of metastases [99,107,123-125,127,137,141]. A postoperative serum proteomics analysis of high-risk breast cancer patients also showed that low expression of ApoA-I was associated with metastatic relapse $[107,134]$. Other studies reported that ApoA-I serum levels were significantly decreased in HCC patients with recurrent disease, as compared to patients in remission, and patients with acute 
lymphoblastic leukemia who achieved remission after receiving chemotherapy displayed significant increases in ApoA-I levels [100,137].

An overall association of HDL/ApoA-I levels with the prognosis of cancer patients treated with surgery, chemotherapy, radiotherapy, or immunotherapy has been concluded in a recent meta-analysis [142]. Indeed, an association with prognosis has been reported in patients with nasopharyngeal carcinoma, non-small cell lung carcinoma, invasive breast ductal adenocarcinoma, esophageal squamous cell carcinoma, colorectal adenocarcinoma, HCC, renal cell carcinoma, and transitional cell carcinoma of the bladder [80-82,85,86,88,89,95,101,102,108,109,135,143]. Likewise, ApoA-I has been proposed as a putative prognostic biomarker in neuroblastoma patients, since ApoA-I serum levels were found significantly lower in patients with high risk tumors [138]. Interestingly, post-treatment ApoA-I levels also seem to confer prognostic significance. A retrospective study of colorectal cancer patients treated with surgery and adjuvant chemotherapy showed that relatively increased levels of HDL-c and ApoA-I, one month after the completion of chemotherapy, were associated with better prognosis [144]. ApoA-I levels have been especially evaluated in response to chemosensitivity. Higher serum ApoA-I were found to be associated to better response to chemotherapy in patients with colorectal cancer, while higher ApoA-I levels secreted in the interstitial fluid of breast tumors were associated with more chemosensitive tumors $[145,146]$. In another study, ApoA-I levels were found to predict response to IMA901, the first therapeutic vaccine used in a randomized phase 2 trial for the treatment of patients with advanced renal cell carcinoma. Specifically, high levels of ApoA-I were associated with better overall survival [147].

Possible associations of ApoA-I genetic variations with cancer parameters have also been noted. A positive association was found between the ApoA-I (-75) A allele and breast cancer risk, and between the ApoA-I (+83) T allele and the development of lymph node metastasis [110]. Another study showed that breast cancer patients carrying an ApoA-I-rs670 A allele showed a less favorable phenotype at presentation, with absence of hormone receptor expression and lymph node metastases in comparison to $\mathrm{G} / \mathrm{G}$ carriers. Moreover, rs670 A/A carrying patients had more frequent recurrences and inferior survival in comparison to patients with no A alleles [111].

Although the majority of studies have shown an inverse association of ApoA-I levels with the development and progression of various cancers, positive correlations have been reported. For example, ApoA-I levels are upregulated in the serum of patients with early stage gastric adenocarcinoma, recurrent head and neck squamous cell carcinoma and retinoblastoma and in the urine of patients with transitional cell carcinoma of the bladder, while a nested case-control study reported that HDL-c/ApoA-I levels were positively associated with the risk for the development of breast cancer $[79,90,112,113,130$, 131,139]. Also, pro-ApoA-I levels were found upregulated in the serum of lung cancer patients with brain metastases and overexpressed at transcriptional level in metastases of colon adenocarcinoma to the liver suggesting that, in these particular situations, ApoA-I levels could be used as a biomarker for the extension of the disease to the brain and the liver, respectively $[87,96,148]$. It is unclear whether the positive correlation between ApoA-I levels and cancer parameters reported in a minority of studies are specific reflecting, in these particular situations, tumor promoting processes, associated with increased cholesterol uptake of malignant cells through the HDL/SR-BI pathway, as proposed by some studies [149-151].

Even though the bulk of data suggest that increased levels of ApoA-I/HDL could be protective against cancer development and progression, the reported ApoA-I/HDL alterations could be a consequence and not a cause of the carcinogenesis process. In such a case, ApoA-I could still be a useful biomarker for early cancer detection, or for better management stratification and follow up of cancer patients. However, a causative role would imply that interventions aiming at increasing the levels and functionality of ApoA-I could contribute to better cancer prevention and therapy. 


\section{ApoA-I Exhibits Tumor Suppressive Activity: Evidence from In Vitro Studies}

A number of in vitro studies suggest that ApoA-I affects the proliferative, survival, and migratory behavior of various carcinoma cells, largely through cell-autonomous mechanisms (summarily presented in Table 2).

Table 2. In vitro studies of ApoA-I in cancer.

\begin{tabular}{|c|c|c|c|c|}
\hline Type of Cancer & In Vitro System & Apo A-I Manipulation & $\begin{array}{c}\text { Biologic Effect and } \\
\text { Associated Mechanisms }\end{array}$ & Ref. \\
\hline \multirow{4}{*}{$\begin{array}{l}\text { ovarian carcinoma } \\
\text { (OC) }\end{array}$} & murine ovarian cell line ID8 & $\begin{array}{l}\text { treatment with human ApoA-I or } \\
\text { ApoA-I mimetics (L-5F and L-4F) }\end{array}$ & $\begin{array}{c}\downarrow \downarrow \text { viability and } \\
\text { proliferation } \\
\downarrow \text { LPA-induced viability }\end{array}$ & [152] \\
\hline & murine ovarian cell line ID8 & $\begin{array}{l}\text { treatment with the ApoA-I mimetic } \\
\text { D- } 4 \mathrm{~F}\end{array}$ & $\begin{array}{c}\downarrow \text { viability and } \\
\text { proliferation } \\
\downarrow \text { oxidative stress } \\
\uparrow \text { MnSOD expression and } \\
\text { activity }\end{array}$ & [153] \\
\hline & $\begin{array}{c}\text { cis-platinum-resistant human } \\
\text { ovarian cell lines (OVCAR5, SKOV3, } \\
\text { OV2008, and A2780) }\end{array}$ & $\begin{array}{l}\text { treatment with the ApoA-I mimetic } \\
\qquad \text { L- } 4 \mathrm{~F}\end{array}$ & $\begin{array}{l}\downarrow \text { viability and } \\
\text { invasiveness } \\
\downarrow \text { AKT activation }\end{array}$ & [154] \\
\hline & $\begin{array}{l}\text { cis-platinum-resistant human } \\
\text { ovarian cell lines (SKOV3, OV2008) }\end{array}$ & $\begin{array}{l}\text { treatment with the ApoA-I mimetic } \\
\qquad \mathrm{L}-5 \mathrm{~F}\end{array}$ & $\begin{array}{l}\downarrow \text { LPA-induced cell } \\
\text { viability and VEGF } \\
\text { production }\end{array}$ & [155] \\
\hline $\begin{array}{l}\text { hepatocellular } \\
\text { carcinoma (HCC) }\end{array}$ & $\begin{array}{l}\text { human HCC cell lines (MHCC97H } \\
\text { and Huh7) }\end{array}$ & treatment with recombinant ApoA-I & $\begin{array}{c}\downarrow \text { proliferation (cell cycle } \\
\text { arrest) } \\
\uparrow \text { apoptosis } \\
\downarrow \text { MMP2/9 } \\
\downarrow \text { VEGF inhibition of the } \\
\text { MAPK signaling pathway }\end{array}$ & [100] \\
\hline $\begin{array}{l}\text { colon } \\
\text { adenocarcinoma } \\
(\mathrm{CA})\end{array}$ & $\begin{array}{l}\text { human CA cell lines (DLD-1 and } \\
\text { Caco-2) overexpressing ABCA1 }\end{array}$ & $\begin{array}{l}\text { transgenic overexpression of } \\
\text { ApoA-I, treatment with } \\
\text { recombinant ApoA-I or apabetalone } \\
\text { (a BET inhibitor, inducer of ApoA-I } \\
\text { production) }\end{array}$ & $\begin{array}{c}\downarrow \text { cell proliferation, } \\
\text { migration and invasion } \\
\text { modulation of ABCA1 } \\
\text { expression through COX-2 } \\
\text { downregulation } \\
\text { compensation for } \\
\text { ABCA1-dependent } \\
\text { excessive export of } \\
\text { cholesterol }\end{array}$ & [157] \\
\hline $\begin{array}{c}\text { breast } \\
\text { adenocarcinoma } \\
\text { (BA) }\end{array}$ & human CA cell line, MCF-7 & $\begin{array}{l}\text { treatment with the ApoA-I mimetic } \\
\qquad \mathrm{D}-4 \mathrm{~F}\end{array}$ & $\begin{array}{l}\downarrow \text { oxLDL-induced } \\
\text { proliferation }\end{array}$ & [159] \\
\hline $\begin{array}{c}\text { pancreatic } \\
\text { adenocarcinoma } \\
\text { (PA) }\end{array}$ & murine PA cell line P7 & $\begin{array}{l}\text { treatment with the ApoA-I mimetic } \\
\qquad \mathrm{L}-4 \mathrm{~F}\end{array}$ & none & [160] \\
\hline
\end{tabular}

$\uparrow$ indicates increase, while $\downarrow$ indicates decrease; ABCA1: ATP-binding cassette transporter 1; COX-2: Cyclooxygenase 2; HIF-1 $\alpha$ : Hypoxia induced factor $1 \alpha$; LPA: lysophosphatidic acid; MAPK: Mitogen-activated protein kinases; MMP2/9: Matrix metalloproteinases 2 and 9; MnSOD: Manganese superoxide dismutase; oxLDL: Oxidized low-density lipoprotein; ROS: Reactive oxygen species; VEGF: Vascular endothelial growth factor. 
HCC cells treated with recombinant ApoA-I undergo G0/1 cell cycle arrest and apoptosis associated with downregulation of mitogen-activated protein kinases 1 and 3 (MAPK1, MAPK3), known for their antiapoptotic function, and upregulation of proapoptotic genes including caspase 5 (casp5), tumor necrosis factor receptor superfamily 10B (TNFRSF10B), and apoptosis protease activating factor 1 (APAF-1) [100]. ApoA-I also induced downregulation of vascular growth factor (VEGF) and matrix metalloproteinases 2 and 9 (MMP2, MMP9) genes, suggesting that ApoA-I may decrease the angiogenetic potential and the ability of HCC cells to remodel extracellular matrix, inhibiting in this way their metastatic potential [100].

A recent study showed that human colon adenocarcinoma (CA) cells stably transfected with ABCA1, exhibit increased proliferative, invasive and migratory behavior, which could be inhibited by simultaneous, transgenic overexpression of ApoA-I, or by exogenous treatment with human recombinant ApoA-I [157]. This inhibition was associated with downregulation of cyclooxygenase 2 (COX-2), a known promoter of colon adenocarcinoma involved in proinflammatory processes. In the same study, apabetalone, a small molecule BET-inhibitor, used in experimental therapeutics of atherosclerosis and known to induce production of ApoA-I, reduced the ABCA1-driven proliferative and invasive behavior of CA cells [157]. Another study showed that treatment of CA cells with the ApoA-I-mimetic peptide L-4F induced G0/1 cell cycle arrest, associated with decreased expression levels of cyclins D1 and A and decreased cell viability [158]. Also, it reduced the survival of CA cells stimulated by lysophosphatidic acid (LPA), a potent bioactive phospholipid, known to decrease its free concentration in the cell culture media [158].

In ovarian carcinoma (OC) cells, treatment with ApoA-I-mimetic peptides D-4F or L-4F was also found to impact proliferation, survival, and migratory behavior associated with reduced lipid peroxidation and hydrogen hyperoxide levels, and to decrease VEGF production and expression of the hypoxia induced factor- $1 \alpha$ (HIF-1 $\alpha$ ) transcription factor $[152,153,155,156]$. Moreover, administration of ApoA-I or various ApoA-I mimetic peptides increases the sensitivity of human OC cells to cisplatin, a classical chemotherapeutic agent, associated with decreased activation of AKT [154]. Also, the ApoA-I mimetic D-4F was shown to reduce the proliferative response of human breast adenocarcinoma cells, stimulated by oxidized low-density lipoprotein (oxLDL) [159].

\section{The Tumor Suppressive Function of ApoA-I: Evidence from Animal Studies}

Accumulating evidence suggests that ApoA-I inhibits the growth of tumors and the metastatic progression of the disease in various animal cancer models (summarily presented in Table 3).

In a melanoma model, mice deficient for ApoA-I showed increased tumor burden and reduced survival. Conversely, transgenic overexpression of human ApoA-I or exogenous administration of ApoA-I protein reduced malignant burden, decreased metastases and increased mouse survival [161]. Melanomas in transgenic mice expressing high levels of ApoA-I showed decreased angiogenesis, reduced expression of MMP9, a matrix-degrading enzyme contributing to the invasive behavior of tumor cells, and reduced levels of survivin, an important antiapoptotic molecule. 
Table 3. Animal studies of ApoA-I in cancer.

\begin{tabular}{|c|c|c|c|c|}
\hline Type of Cancer & Animal Model & Apo A-I Manipulation & $\begin{array}{l}\text { Biologic Effect and } \\
\text { Associated Alterations }\end{array}$ & Ref. \\
\hline \multirow[t]{2}{*}{$\begin{array}{l}\text { melanoma and } \\
\text { non-small lung } \\
\text { carcinoma }\end{array}$} & \multirow[t]{2}{*}{$\begin{array}{l}\text { syngeneic murine melanoma } \\
\text { (B16F10L), human melanoma (A375) } \\
\text { and Lewis lung (murine) carcinoma } \\
\text { cells engrafted subcutaneously or } \\
\text { injected intravenously in a metastatic } \\
\text { cancer mouse model }\end{array}$} & $\begin{array}{l}\text { human ApoA-I transgenic } \\
\text { overexpression or injection of } \\
\text { human ApoA-I }\end{array}$ & $\begin{array}{c}\downarrow \text { tumor growth and } \\
\text { metastasis } \\
\uparrow \text { survival } \\
\downarrow \text { tumor angiogenesis } \\
\downarrow \text { MMP-9 } \\
\downarrow \text { surviving modulation of } \\
\text { the tumor immune } \\
\text { microenvironment: } \\
\downarrow \text { M } 2 \mathrm{M} \varphi \\
\uparrow \mathrm{M} 2 \mathrm{M} \varphi \\
\downarrow \text { MDSCs } \\
\uparrow \mathrm{TILs}\end{array}$ & \multirow[t]{2}{*}[161]{} \\
\hline & & ApoA-I KO & the opposite effects & \\
\hline ovarian carcinoma & $\begin{array}{l}\text { syngeneic murine ovarian carcinoma } \\
\text { cells (ID-8) engrafted subcutaneously } \\
\text { or injected intraperitoneally in mice }\end{array}$ & $\begin{array}{c}\text { transgenic overexpression of } \\
\text { human ApoA-I, or treatment with } \\
\text { ApoA-I mimetic peptides (L-5F, } \\
\text { L-4F, D-4F) }\end{array}$ & $\begin{array}{l}\downarrow \text { tumor growth } \\
\uparrow \text { survival }\end{array}$ & [152] \\
\hline ovarian carcinoma & $\begin{array}{l}\text { syngeneic murine ovarian carcinoma } \\
\text { cells (ID-8) engrafted subcutaneously } \\
\text { in mice }\end{array}$ & $\begin{array}{l}\text { treatment with ApoA-I mimetic } \\
\text { peptides }(\mathrm{L}-5 \mathrm{~F}, \mathrm{~L}-4 \mathrm{~F}, \mathrm{D}-4 \mathrm{~F})\end{array}$ & $\begin{array}{c}\downarrow \text { tumor growth } \\
\downarrow \text { LPA serum levels } \\
\downarrow \text { tumor angiogenesis } \\
\downarrow \text { VEGF (L-5F) } \\
\downarrow \text { HIF- } 1 \alpha \text { expression (L-4F) } \\
\uparrow \text { MnSOD (D-4F) } \\
\downarrow \text { oxidized phospholipids }\end{array}$ & $\begin{array}{l}{[152,} \\
153 \\
155 \\
156]\end{array}$ \\
\hline $\begin{array}{l}\text { colon } \\
\text { adenocarcinoma }\end{array}$ & $\begin{array}{l}\text { AOM/DSS-induced murine colorectal } \\
\text { adenocarcinomas }\end{array}$ & $\begin{array}{l}\text { ApoA-I haploinsufficiency Apo } \\
\qquad A-I^{(+/-)}\end{array}$ & $\begin{array}{c}\uparrow \text { tumor growth and altered } \\
\text { tumor distribution } \\
\text { (proximal extension) } \\
\downarrow \text { survival } \\
\uparrow \text { inflammation } \\
\uparrow \text { tumor cell proliferation } \\
\uparrow \text { IL-6, pSTAT3, NF-kB } \\
\text { signaling }\end{array}$ & {$[61]$} \\
\hline \multirow[t]{2}{*}{$\begin{array}{l}\text { colon } \\
\text { adenocarcinoma }\end{array}$} & $\begin{array}{l}\text { syngeneic murine colon } \\
\text { adenocarcinoma cells CT26 engrafted } \\
\text { subcutaneously in mice }\end{array}$ & \multirow[t]{2}{*}{$\begin{array}{l}\text { treatment with the ApoA-I } \\
\text { mimetic peptide L-4F }\end{array}$} & $\begin{array}{c}\downarrow \text { tumor growth } \\
\downarrow \text { LPA serum levels }\end{array}$ & \multirow[t]{2}{*}{ [158] } \\
\hline & $\begin{array}{l}\text { a murine model for familial } \\
\text { adenomatous polyposis }\left(\mathrm{APC}^{-/+}\right)\end{array}$ & & $\begin{array}{l}\downarrow \text { number and size of colon } \\
\text { polyps }\end{array}$ & \\
\hline $\begin{array}{l}\text { colon } \\
\text { adenocarcinoma } \\
\text { and non-small lung } \\
\text { carcinoma }\end{array}$ & $\begin{array}{c}\text { syngeneic murine colon } \\
\text { adenocarcinoma (CT26) and Lewis } \\
\text { lung carcinoma cells injected } \\
\text { intravenously in a metastatic lung } \\
\text { mouse carcinoma model }\end{array}$ & $\begin{array}{l}\text { treatment with a concentrate of } \\
\text { transgenic tomatoes expressing } \\
\text { the ApoA-I mimetic peptide } 6 \mathrm{~F}\end{array}$ & $\begin{array}{c}\downarrow \text { number of tumors in the } \\
\text { lung } \\
\downarrow \text { Notch signaling } \\
\downarrow \text { oxidized phospholipids } \\
\uparrow \text { osteopontin } \\
\downarrow \text { MDSCs in lung and } \\
\text { intestine tissues }\end{array}$ & [162] \\
\hline $\begin{array}{l}\text { colon and ovarian } \\
\text { adenocarcinoma }\end{array}$ & $\begin{array}{l}\text { syngeneic murine ovarian carcinoma } \\
\text { cells (ID-8) engrafted } \\
\text { intraperitoneally and colon } \\
\text { adenocarcinoma cells (CT26) injected } \\
\text { intravenously in a metastatic lung } \\
\text { carcinoma mouse model }\end{array}$ & $\begin{array}{l}\text { treatment with a concentrate of } \\
\text { transgenic tomatoes expressing } \\
\text { the ApoA-I mimetic peptide } 6 \mathrm{~F}\end{array}$ & $\begin{array}{l}\downarrow \text { tumor growth in the } \\
\text { abdomen } \\
\downarrow \text { number of tumors in the } \\
\text { lung }\end{array}$ & [163] \\
\hline $\begin{array}{l}\text { pancreatic } \\
\text { adenocarcinoma }\end{array}$ & $\begin{array}{l}\text { syngeneic murine pancreatic } \\
\text { adenocarcinoma cells line P7 } \\
\text { orthotopically engrafted in mice }\end{array}$ & $\begin{array}{l}\text { treatment with the ApoA-I } \\
\text { mimetic peptide L-4F }\end{array}$ & $\begin{array}{l}\downarrow \text { tumor growth in the } \\
\text { abdomen } \\
\downarrow \mathrm{M} 2 \mathrm{M} \varphi \text { in tumors }\end{array}$ & [160] \\
\hline \multirow[t]{2}{*}{$\begin{array}{c}\text { breast } \\
\text { adenocarcinoma }\end{array}$} & \multirow[t]{2}{*}{$\begin{array}{c}\text { mammary tumour virus-polyoma } \\
\text { middle T-antigen transgenic (PyMT) } \\
\text { mice }\end{array}$} & $\begin{array}{l}\text { treatment with the ApoA-I } \\
\text { mimetic peptide D-4F }\end{array}$ & $\begin{array}{c}\uparrow \text { latency of tumor } \\
\text { appearance } \\
\downarrow \text { tumor growth } \\
\downarrow \text { oxidized LDL plasma } \\
\text { levels }\end{array}$ & \multirow[t]{2}{*}{ [159] } \\
\hline & & $\begin{array}{l}\text { transgenic overexpression of } \\
\text { human ApoA-I in PyMT mice }\end{array}$ & none & \\
\hline
\end{tabular}

$\uparrow$ indicates increase, while $\downarrow$ indicates decrease; AOM: azoxymethane; DSS: dextran sodium sulfate; HIF $\alpha$ : Hypoxia induced factor- $1 \alpha$; LPA: Lysophosphatidic acid; MnSOD: Manganese superoxide dismutase; MMP-9: Matrix metalloproteinases 9; M $\varphi$ : macrophages; NF-kB: Nuclear factor kappa-light-chain-enhancer of activated B cells; TIL: tumor infiltrating lymphocytes; MDSC: myeloid-derived suppressor cells; pSTAT3: phosphorylated signal transducer and activator of transcription 3; PyMT: mammary tumour virus-polyoma middle T-antigen transgenic; VEGF: Vascular endothelial growth factor. 
In line with the reported in vitro effects of ApoA-I mimetic peptides in OC, transgenic overexpression of human ApoA-I in a murine model of OC, or exogenous administration of D4-F, L5-F, and L4-F decreased tumor burden and increased survival [152]. The levels of LPA, VEGF, and HIF- $1 \alpha$ in mice treated with ApoA-I mimetic peptides were found significantly reduced relative to control animals $[152,155,156,163]$. Another study showed that the inhibitory effects of the ApoA-I mimetic peptide D4-F was dependent on the upregulation of the antioxidant enzyme manganese superoxide dismutase (MnSOD), as silencing of the gene in the engrafted cells by a MnSOD-specific shRNA abolished the D4-F-tumor suppressing effects, suggesting that the antioxidant activity downstream of ApoA-I may be essential for its tumor suppressor properties in OC [153].

Patients with inflammatory bowel disease have increased risk for the development of CA [164]. In both humans with ulcerative colitis and mouse models of colitis-associated carcinogenesis, CA develops predominantly in the distal part of the large intestine. Intriguingly, ApoA- $\mathrm{I}^{-{ }^{-}}$and ApoA-I ${ }^{+-}$mice develop more numerous and larger tumors that display extension to the proximal part of the colon [61]. These differences were accompanied by a higher tumor cell proliferation rate in the ApoA-I ${ }^{+/-}$group and by elevated expression levels of activated STAT3 [61], a transcription factor involved in inflammatory and tumor-promoting processes [165]. In another study, treatment with the ApoA-I mimetic peptide L-4F significantly reduced the size and number of polyps in Adenomatosis Polyposis Coli (APC) $)^{-/+}$mice, a mouse model for human familial adenomatous polyposis [158]. Interestingly, the administration of ApoA-I mimetic peptides or the overexpression of ApoA-I not only reduced primary tumor burden but also metastasis of CA cells in the lung [161,162].

The tumor suppressive activity of ApoA-I has also been demonstrated in an orthotopically implanted mouse model of pancreatic adenocarcinoma and in a breast cancer mouse model, the latter being associated with reduction in plasma oxLDL $[159,160]$. Interestingly, dysfunctional, oxidized ApoA-I/HDL has been reported to promote breast cancer metastasis in mice [166]. Other animal studies have reported inverse association of serum ApoA-I levels with the progression of lung and gastric cancer in the mouse [167-170].

\section{Anti-Inflammatory and Immune-Modulating Mechanisms Are Involved in the Tumor Suppressive Activity of ApoA-I}

Collectively, the aforementioned in vitro and animal studies provide convincing evidence that ApoA-I affects many of the originally proposed hallmarks of cancer [171], including sustained proliferative signaling, resistance to cell death, angiogenesis, and activation of invasion and metastasis (Figure 2).

Accumulating findings suggest that ApoA-I also targets one of the more recently proposed hallmarks of cancer, that of tumor promoting inflammation. Chronic inflammation, caused by dysbiosis, plays a pivotal role in cancer promotion in the liver and colon [172,173], tissues known to produce ApoA-I, and inflammatory mechanisms emanating from TLR4 stimulation on cancer cells contribute to malignant growth in this context $[172,174]$. The concept that the anti-inflammatory properties of ApoA-I participate in the protection against colon cancer is highlighted by the fact that ApoA-I ameliorates colitis-promoted colon carcinogenesis in parallel with the attenuation of TLR4-mediated activation of key inflammatory regulators, including $\mathrm{NF}_{-} \mathrm{B}, \mathrm{STAT} 3$, and IL-6 [61]. This is further supported by studies demonstrating reduction of various oxidized lipids and enzymes involved in inflammation, such as COX-2, by ApoA-I in models of colon or ovarian cancer $[156,157]$.

Given the role of ApoA-I/HDL in RCT (see Section 1), deregulation of this pathway may have systemic effects on lipid and cholesterol accumulation which, in turn, may impact on immune cell homeostasis and inflammatory reactions that are linked to malignancy $[175,176]$. Moreover, modulation of the integrity of cholesterol-enriched microdomains in the plasma membrane, which function as docking sites for several receptors, may alter the activation of signaling pathways in many cells of the immune system [47]. Additionally, ligation of HDL particles to specific ApoA-I receptors (ABCA1, ABCG1 etc.) promoting the RCT may result in broader "outside-in" signaling events which have 
been reported to enable macrophages to convey anti-inflammatory effects [177]. It is also possible that ApoA-I, internalized by the responsive cells may further modify signaling mechanisms.

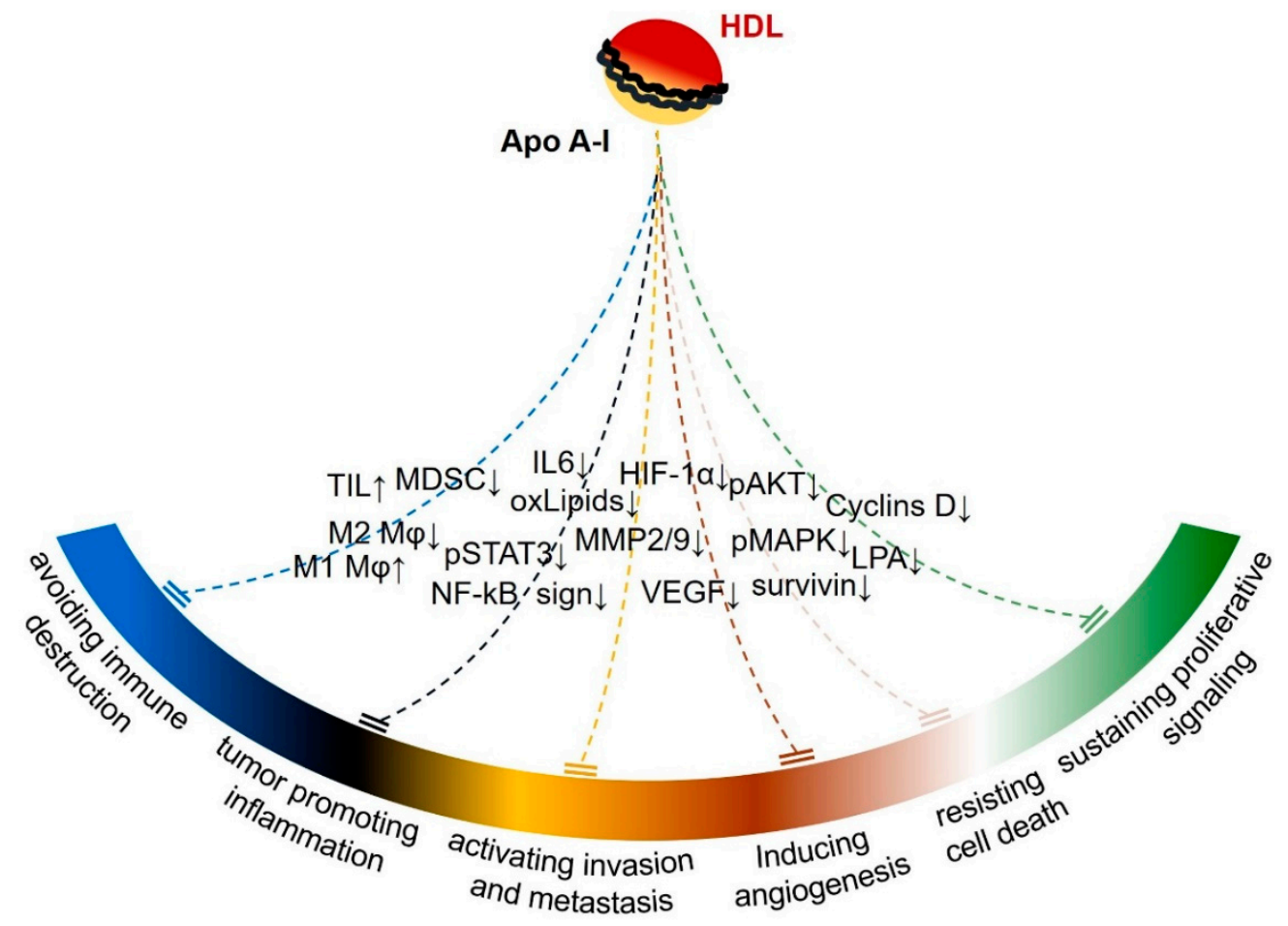

Figure 2. The antitumor activity of ApoA-I in relation to the proposed hallmarks of cancer. Cancer hallmarks affected by ApoA-I, in association with some of the corresponding molecular or cellular mediators reported by various in vitro and animal studies, are shown. It is possible that some mediators may affect more than one hallmark and additional hallmark features, not yet investigated, such as deregulated cellular energetic and genome instability and mutation, may be affected by the tumor suppressive activity of ApoA-I. Abbreviations for various molecules and cell types are explained in the main text. $\uparrow$ increase; $\downarrow$ decrease.

As the modulation of the inflammatory tumor microenvironment is exploited by cancer cells to buffer the attack of the immune system, the effects of ApoA-I on cancer inflammatory and immuno-editing processes seem interconnected [178,179]. Indeed, the ability of ApoA-I to inhibit melanoma growth is attenuated, although not abolished, in mice lacking the humoral and the cellular components of specific immunity [161]. Immuno-phenotyping of tumors developed in ApoA-I transgenic mice showed a reduction in myeloid derived suppressor cells (MDSCs), a heterogeneous immature myeloid cell population of granulocytic or monocytic origin capable of inhibiting the immune response, but an increase in tumor infiltrating cytotoxic T cells (TIL) and CD11b+ macrophages $[161,180]$. The latter is of particular interest as ApoA-I has been implicated in the conversion of tumor associated macrophages (TAM) from M2 to M1 phenotype that associates with enhanced antitumor properties [161]. Along these lines, administration of the ApoA-I mimetic peptide L4-F resulted in decreased recruitment of M2 macrophages to the tumors [160]. However, the exact mechanisms involved in the regulation of MDSC and M1/2 phenotype by ApoA-I remain elusive.

One mechanism by which ApoA-I mimetic peptides impact on antitumor immunity entails an increase in the levels of specific oxidized lipids to activate Notch signaling in the intestine which, in turn, leads to higher numbers of patrolling monocytes in lamina propria. This treatment also reduces 25-hydroxycholesterol with concomitant decrease in osteopontin expression in enterocytes and lower numbers of MDSCs in lamina propria [162].

The notion that the tumor suppressive properties of ApoA-I are connected to the modulation of anticancer immunity is further supported by recent animal studies that investigated the effects of the 
ApoA-I receptors, Abcg1 and Abca1, on cancer growth in connection with parameters of anticancer immunity [181,182]. It was shown that myeloid specific deficiency of Abcg1 or Abca1 was associated with decreased tumor growth, increased polarization of TAMs towards M1 phenotype, and decreased numbers of specific MDSCs subsets in the tumors [181,182].

\section{Tools for Therapeutic Targeting of ApoA-I}

The tools for therapeutic targeting of ApoA-I originated from an effort to discover strategies exploiting the atheroprotective properties of HDL [183]. Some of these strategies aim to indirectly augment the ApoA-I and HDL-c levels by inhibiting endothelial lipase and CETP or to augment RCT by activating LCAT or the liver $X$ receptors (LXRs), members of the nuclear receptor superfamily that orchestrate the activation of many genes promoting RCT and intestinal HDL production [183-187]. None of these approaches have been thoroughly tested in cancer studies.

However, strategies aiming in directly augmenting ApoA-I, or mimicking ApoA-I functionality have already been used successfully in preclinical cancer studies (Tables 2 and 3). The first of these approaches can be accomplished by intravenous administration of autologous delipidated HDL, purified native ApoA-I, or recombinant ApoA-I Milano protein, a mutated "hyperfunctional" ApoA-I variant discovered in a cohort of Italian patients, in complexes with phosphatidylcholine $[188,189]$. Although administration of such reconstituted HDL has shown antitumor activity in various preclinical models, it is a laborious and expensive strategy, difficult for a broad application in cancer patients.

Another approach utilizes ApoA-I mimetic peptides, synthesized on the basis of $\alpha$-amphipathic helical repeating structure of ApoA-I, aiming to mimic the function of ApoA-I [190]. Many of them are 18 amino acids long and modified in various ways for augmenting stability and lipid-binding properties. Some of them including peptides composed of D-amino acids, being resistant to protease degradation, can be given orally, and have been expressed transgenically in tomatoes, in an effort to increase their practical utility [191]. Their action in small intestine tissues has been shown to be critical for their anti-atherogenic value in animal models [192]. These agents can produce HDL-like particles that promote cholesterol efflux and have shown antiatherogenic, antioxidant, anti-inflammatory, and antitumor activity in preclinical models $[190,193]$. Their function is not exactly equivalent to ApoA-I, since some are designed to better mimic one or another function of ApoA-I. For example, some of them have far superior ability, in comparison to ApoA-I, to neutralize pathogenic lipids such as LPA [190,192]. This may explain the discrepancy in the findings regarding alterations of LPA levels among various cancer studies using ApoA-I mimetics and ApoA-I [152,161] as well as differences in the antitumor activity [159].

Although ApoA-I mimetics have shown promising therapeutic potential in various preclinical models, recent clinical trials in the context of CVD have failed to demonstrate clear clinical benefit [194]. However, all clinical trials so far have been performed in the setting of acute coronary syndrome regarding patients with advanced disease in need for aggressive intervention. It is possible that future, carefully designed clinical trials, investigating a longer period of administration time in combination with established chemotherapeutic or immunotherapeutic agents, could be more informative for the therapeutic potential of ApoA-I mimetics in cancer.

\section{Open Questions for Future Research}

In vitro and in vivo experimental studies have shown that the tumor suppressive activity of ApoA-I targets cell-autonomous and cell-nonautonomous survival mechanisms (Figure 2). Which mechanism is pivotal for the antitumor activity of ApoA-I has not been fully elucidated. The prevailing view is that the anti-inflammatory action of ApoA-I is important for the enhanced antitumor immunity. Recent studies have shown that chronic inflammation is an essential mechanism contributing to the attenuation of innate and specific immunity against cancer [195]. Although there is evidence that ApoA-I may modify the anticancer immune response, detailed investigation of the effects of ApoA-I on immune checkpoints (for example programmed death ligand-1, PD-L1) in cancer cells or the cells of 
tumor microenvironment and on anticancer immunity has not been performed [161]. The effects of ApoA-I on the outcome of cancer immunotherapy also remains to be elucidated.

Whilst the anti-inflammatory action of ApoA-I has attracted most attention, additional hallmarks of cancer may be influenced by ApoA-I. Findings showing that ApoA-I can affect the expression levels of transcription factors, such as HIF- $1 \alpha$, suggest that ApoA-I may have profound effects on metabolic pathways in cancer cells $[156,196]$. However, detailed alterations in energetic metabolism of cancer cells, including lipid metabolism, after treatment with ApoA-I or ApoA-I mimetic peptides have not been explored. The antioxidative function of ApoA-I has been demonstrated in various cancer models $[153,156]$. Although it is known that increased oxidation stress may contribute to DNA damage and increased mutational burden, the effects of ApoA-I on DNA damage response mechanisms have not been explored. ApoA-I itself is subject to oxidative damage and carbonylation which have been linked to apolipoprotein dysfunction and a pathogenic role in Alzheimer disease [197]. Whether these modifications may also have a role in immunity, inflammation and cancer remain obscure.

Most efforts to clarify the mechanism of the anti-inflammatory and antitumor activity of ApoA-I have focused on the interaction of ApoA-I with the receptors ABCA1, ABCG1, and SR-BI. For example, it has been shown that mice deficient in ABCG1 and ABCA1, when fed a "western"-type diet, display reduced growth of tumors derived from subcutaneously engrafted melanoma or bladder carcinoma cells, while other studies have attempted to associate ABCA1 with epithelial mesenchymal transition in breast cancer $[181,182,198,199]$. Although deficiency of ABCA1 or ABCG1 transporters does not always mirror the ApoA-I effect, at first glance, it seems counterintuitive that deficiency of ABCA1 and excess of ApoA-I, which affect RCT in opposite directions, both may contribute to tumor suppression. However, it is possible that some of the anti-inflammatory and antitumor activities of ApoA-I may be mediated by other receptors. For example, the beta-chain of ATP F1 synthase was discovered to represent a high affinity receptor of lipid poor ApoA-I at the cell membrane (known also as ecto-F1F0-ATPase; Figure 1) [25]. Binding of ApoA-I to this receptor was found to stimulate the hydrolysis of extracellular ATP to ADP and phosphate, implying that ApoA-I may affect signaling emanating from cell membrane P2 purinergic receptors, many of which have been shown to modify inflammatory and immune responses and tumor growth $[26,200]$. Although one of these receptors, P2Y13, was shown to mediate the signal from ecto-F1F0-ATPase to SR-BI for promoting HDL cell internalization, ecto-F1F0-ATPase-mediated effects of ApoA-I on P2 purinergic receptor signaling important for immune responses and cancer biology have not been investigated.

ApoA-I levels have been shown to be affected by chemotherapy. Examination of serum lipid profiles in breast cancer patients revealed a significant reduction of ApoA-I and HDL levels upon completion of chemotherapy $[141,201]$. ApoA-I protein levels were reduced by doxorubicin, while they remained unaffected by cyclophosphamide and paclitaxel treatment, in agreement with in vitro experimental findings [201]. Postchemotherapy infections are an important complication of cancer patients, and the ability of ApoA-I to neutralize bacterial products represents an important aspect of innate immunity [202]. However, the impact of ApoA-I on the incidence and outcome of postchemotherapy bacterial infections has not been investigated in epidemiologic or preclinical studies.

\section{Conclusions}

In conclusion, combined epidemiologic, clinicopathologic, and preclinical experimental research has shown that ApoA-I could represent not only a useful cancer biomarker, but a biochemical variable of the organism that could be modified for more effective cancer prevention and treatment. The exact mechanisms involved in the antitumor activity of ApoA-I and the evaluation of its antitumor therapeutic potential merits further investigations.

Author Contributions: Conceptualization and Literature review, K.G., D.V. and E.D.; Writing-Original Draft Preparation, K.G. and D.V.; Writing-Review \& Editing and Supervision, E.D. All authors have read and approved the submitted version of the manuscript. 
Funding: This study has been co-financed by the Operational Program "Human Resources Development, Education and Lifelong Learning" (KA 10071) and is co-financed by the European Union (European Social Fund) and Greek national funds.

Acknowledgments: We thank Aristides G Eliopoulos (Dept. of Biology, Medical School, National and Kapodistrian University of Athens) for constructive discussions and comments on the manuscript.

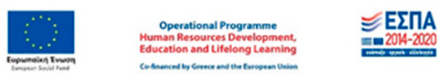

Conflicts of Interest: The authors declare no conflict of interest.

\section{References}

1. Gordon, S.M.; Hofmann, S.; Askew, D.S.; Davidson, W.S. High density lipoprotein: It's not just about lipid transport anymore. Trends Endocrinol. Metab. 2011, 22, 9-15. [CrossRef] [PubMed]

2. Levine, A.J.; Puzio-Kuter, A.M. The control of the metabolic switch in cancers by oncogenes and tumor suppressor genes. Science 2010, 330, 1340-1344. [CrossRef] [PubMed]

3. Zamanian-Daryoush, M.; DiDonato, J.A. Apolipoprotein A-I and Cancer. Front. Pharmacol. 2015, 6, 265. [CrossRef] [PubMed]

4. Barker, W.C.; Dayhoff, M.O. Evolution of lipoproteins deduced from protein sequence data. Comp. Biochem. Physiol. B Comp. Biochem. 1977, 57, 309-315. [CrossRef]

5. Fitch, W.M. Phylogenies constrained by the crossover process as illustrated by human hemoglobins and a thirteen-cycle, eleven-amino-acid repeat in human apolipoprotein A-I. Genetics 1977, 86, 623-644. [PubMed]

6. Li, W.H.; Tanimura, M.; Luo, C.C.; Datta, S.; Chan, L. The apolipoprotein multigene family: Biosynthesis, structure, structure-function relationships, and evolution. J. Lipid Res. 1988, 29, 245-271. [PubMed]

7. McLachlan, A.D. Repeated helical pattern in apolipoprotein-A-I. Nature 1977, 267, 465-466. [CrossRef] [PubMed]

8. Bashtovyy, D.; Jones, M.K.; Anantharamaiah, G.M.; Segrest, J.P. Sequence conservation of apolipoprotein A-I affords novel insights into HDL structure-function. J. Lipid Res. 2011, 52, 435-450. [CrossRef] [PubMed]

9. Kardassis, D.; Mosialou, I.; Kanaki, M.; Tiniakou, I.; Thymiakou, E. Metabolism of HDL and its regulation. Curr. Med. Chem. 2014, 21, 2864-2880. [CrossRef]

10. Halley, P.; Kadakkuzha, B.M.; Faghihi, M.A.; Magistri, M.; Zeier, Z.; Khorkova, O.; Coito, C.; Hsiao, J.; Lawrence, M.; Wahlestedt, C. Regulation of the apolipoprotein gene cluster by a long noncoding RNA. Cell Rep. 2014, 6, 222-230. [CrossRef]

11. Azrolan, N.; Odaka, H.; Breslow, J.L.; Fisher, E.A. Dietary fat elevates hepatic apoA-I production by increasing the fraction of apolipoprotein A-I mRNA in the translating pool. J. Biol. Chem. 1995, 270, 19833-19838. [CrossRef] [PubMed]

12. Bloedon, L.T.; Dunbar, R.; Duffy, D.; Pinell-Salles, P.; Norris, R.; DeGroot, B.J.; Movva, R.; Navab, M.; Fogelman, A.M.; Rader, D.J. Safety, pharmacokinetics, and pharmacodynamics of oral apoA-I mimetic peptide D-4F in high-risk cardiovascular patients. J. Lipid Res. 2008, 49, 1344-1352. [CrossRef] [PubMed]

13. Reddy, S.T.; Navab, M.; Anantharamaiah, G.M.; Fogelman, A.M. Apolipoprotein A-I mimetics. Curr. Opin. Lipidol. 2014, 25, 304-308. [CrossRef] [PubMed]

14. Reddy, S.T.; Navab, M.; Anantharamaiah, G.M.; Fogelman, A.M. Searching for a successful HDL-based treatment strategy. Biochim. Biophys. Acta 2014, 1841, 162-167. [CrossRef] [PubMed]

15. Shah, A.S.; Tan, L.; Long, J.L.; Davidson, W.S. Proteomic diversity of high density lipoproteins: Our emerging understanding of its importance in lipid transport and beyond. J. Lipid Res. 2013, 54, 2575-2585. [CrossRef]

16. Shao, B.; Heinecke, J.W. Quantifying HDL proteins by mass spectrometry: How many proteins are there and what are their functions? Expert Rev. Proteom. 2018, 15, 31-40. [CrossRef] [PubMed]

17. Duong, P.T.; Weibel, G.L.; Lund-Katz, S.; Rothblat, G.H.; Phillips, M.C. Characterization and properties of pre beta-HDL particles formed by ABCA1-mediated cellular lipid efflux to apoA-I. J. Lipid Res. 2008, 49, 1006-1014. [CrossRef] [PubMed]

18. Rosenson, R.S.; Brewer, H.B., Jr.; Chapman, M.J.; Fazio, S.; Hussain, M.M.; Kontush, A.; Krauss, R.M.; Otvos, J.D.; Remaley, A.T.; Schaefer, E.J. HDL measures, particle heterogeneity, proposed nomenclature, and relation to atherosclerotic cardiovascular events. Clin. Chem. 2011, 57, 392-410. [CrossRef] [PubMed] 
19. Wang, N.; Silver, D.L.; Costet, P.; Tall, A.R. Specific binding of ApoA-I, enhanced cholesterol efflux, and altered plasma membrane morphology in cells expressing ABC1. J. Biol. Chem. 2000, 275, 33053-33058. [CrossRef] [PubMed]

20. Liang, H.Q.; Rye, K.A.; Barter, P.J. Cycling of apolipoprotein A-I between lipid-associated and lipid-free pools. Biochim. Biophys. Acta 1995, 1257, 31-37. [CrossRef]

21. Sankaranarayanan, S.; Oram, J.F.; Asztalos, B.F.; Vaughan, A.M.; Lund-Katz, S.; Adorni, M.P.; Phillips, M.C.; Rothblat, G.H. Effects of acceptor composition and mechanism of ABCG1-mediated cellular free cholesterol efflux. J. Lipid Res. 2009, 50, 275-284. [CrossRef] [PubMed]

22. Rye, K.A.; Hime, N.J.; Barter, P.J. Evidence that cholesteryl ester transfer protein-mediated reductions in reconstituted high density lipoprotein size involve particle fusion. J. Biol. Chem. 1997, 272, 3953-3960. [CrossRef] [PubMed]

23. Acton, S.; Rigotti, A.; Landschulz, K.T.; Xu, S.; Hobbs, H.H.; Krieger, M. Identification of scavenger receptor SR-BI as a high density lipoprotein receptor. Science 1996, 271, 518-520. [CrossRef] [PubMed]

24. Kozarsky, K.F.; Donahee, M.H.; Rigotti, A.; Iqbal, S.N.; Edelman, E.R.; Krieger, M. Overexpression of the HDL receptor SR-BI alters plasma HDL and bile cholesterol levels. Nature 1997, 387, 414-417. [CrossRef] [PubMed]

25. Martinez, L.O.; Jacquet, S.; Esteve, J.P.; Rolland, C.; Cabezon, E.; Champagne, E.; Pineau, T.; Georgeaud, V.; Walker, J.E.; Terce, F.; et al. Ectopic beta-chain of ATP synthase is an apolipoprotein A-I receptor in hepatic HDL endocytosis. Nature 2003, 421, 75-79. [CrossRef] [PubMed]

26. Martinez, L.O.; Najib, S.; Perret, B.; Cabou, C.; Lichtenstein, L. Ecto-F1-ATPase/P2Y pathways in metabolic and vascular functions of high density lipoproteins. Atherosclerosis 2015, 238, 89-100. [CrossRef] [PubMed]

27. Christensen, E.I.; Gburek, J. Protein reabsorption in renal proximal tubule-function and dysfunction in kidney pathophysiology. Pediatr. Nephrol. 2004, 19, 714-721. [CrossRef]

28. Glass, C.; Pittman, R.C.; Weinstein, D.B.; Steinberg, D. Dissociation of tissue uptake of cholesterol ester from that of apoprotein A-I of rat plasma high density lipoprotein: Selective delivery of cholesterol ester to liver, adrenal, and gonad. Proc. Natl. Acad. Sci. USA 1983, 80, 5435-5439. [CrossRef] [PubMed]

29. Catapano, A.L.; Pirillo, A.; Bonacina, F.; Norata, G.D. HDL in innate and adaptive immunity. Cardiovasc. Res. 2014, 103, 372-383. [CrossRef]

30. Biedzka-Sarek, M.; Metso, J.; Kateifides, A.; Meri, T.; Jokiranta, T.S.; Muszynski, A.; Radziejewska-Lebrecht, J.; Zannis, V.; Skurnik, M.; Jauhiainen, M. Apolipoprotein A-I exerts bactericidal activity against Yersinia enterocolitica serotype O:3. J. Biol. Chem. 2011, 286, 38211-38219. [CrossRef]

31. Perez-Morga, D.; Vanhollebeke, B.; Paturiaux-Hanocq, F.; Nolan, D.P.; Lins, L.; Homble, F.; Vanhamme, L.; Tebabi, P.; Pays, A.; Poelvoorde, P.; et al. Apolipoprotein L-I promotes trypanosome lysis by forming pores in lysosomal membranes. Science 2005, 309, 469-472. [CrossRef] [PubMed]

32. Singh, I.P.; Chopra, A.K.; Coppenhaver, D.H.; Ananatharamaiah, G.M.; Baron, S. Lipoproteins account for part of the broad non-specific antiviral activity of human serum. Antivir. Res. 1999, 42, 211-218. [CrossRef]

33. Jiao, Y.L.; Wu, M.P. Apolipoprotein A-I diminishes acute lung injury and sepsis in mice induced by lipoteichoic acid. Cytokine 2008, 43, 83-87. [CrossRef] [PubMed]

34. Wurfel, M.M.; Kunitake, S.T.; Lichenstein, H.; Kane, J.P.; Wright, S.D. Lipopolysaccharide (LPS)-binding protein is carried on lipoproteins and acts as a cofactor in the neutralization of LPS. J. Exp. Med. 1994, 180, 1025-1035. [CrossRef] [PubMed]

35. Levine, D.M.; Parker, T.S.; Donnelly, T.M.; Walsh, A.; Rubin, A.L. In vivo protection against endotoxin by plasma high density lipoprotein. Proc. Natl. Acad. Sci. USA 1993, 90, 12040-12044. [CrossRef]

36. Wang, Y.; Zhu, X.; Wu, G.; Shen, L.; Chen, B. Effect of lipid-bound apoA-I cysteine mutants on lipopolysaccharide-induced endotoxemia in mice. J. Lipid Res. 2008, 49, 1640-1645. [CrossRef] [PubMed]

37. Morin, E.E.; Guo, L.; Schwendeman, A.; Li, X.A. HDL in sepsis - risk factor and therapeutic approach. Front. Pharmacol. 2015, 6, 244. [CrossRef] [PubMed]

38. Wendel, M.; Paul, R.; Heller, A.R. Lipoproteins in inflammation and sepsis. II. Clinical aspects. Intensive Care Med. 2007, 33, 25-35. [CrossRef]

39. Bottazzi, B.; Doni, A.; Garlanda, C.; Mantovani, A. An integrated view of humoral innate immunity: Pentraxins as a paradigm. Annu. Rev. Immunol. 2010, 28, 157-183. [CrossRef] 
40. Norata, G.D.; Marchesi, P.; Pirillo, A.; Uboldi, P.; Chiesa, G.; Maina, V.; Garlanda, C.; Mantovani, A.; Catapano, A.L. Long pentraxin 3, a key component of innate immunity, is modulated by high-density lipoproteins in endothelial cells. Arterioscler. Thromb. Vasc. Biol. 2008, 28, 925-931. [CrossRef]

41. Cabana, V.G.; Siegel, J.N.; Sabesin, S.M. Effects of the acute phase response on the concentration and density distribution of plasma lipids and apolipoproteins. J. Lipid Res. 1989, 30, 39-49. [PubMed]

42. Van Leeuwen, H.J.; Heezius, E.C.; Dallinga, G.M.; Van Strijp, J.A.; Verhoef, J.; Van Kessel, K.P. Lipoprotein metabolism in patients with severe sepsis. Crit. Care Med. 2003, 31, 1359-1366. [CrossRef] [PubMed]

43. Van Lenten, B.J.; Hama, S.Y.; De Beer, F.C.; Stafforini, D.M.; McIntyre, T.M.; Prescott, S.M.; La Du, B.N.; Fogelman, A.M.; Navab, M. Anti-inflammatory HDL becomes pro-inflammatory during the acute phase response. Loss of protective effect of HDL against LDL oxidation in aortic wall cell cocultures. J. Clin. Investig. 1995, 96, 2758-2767. [CrossRef] [PubMed]

44. Hamilton, K.K.; Zhao, J.; Sims, P.J. Interaction between apolipoproteins A-I and A-II and the membrane attack complex of complement. Affinity of the apoproteins for polymeric C9. J. Biol. Chem. 1993, 268, 3632-3638. [PubMed]

45. Doni, A.; D'Amico, G.; Morone, D.; Mantovani, A.; Garlanda, C. Humoral innate immunity at the crossroad between microbe and matrix recognition: The role of PTX3 in tissue damage. Semin Cell Dev. Biol. 2017, 61, 31-40. [CrossRef] [PubMed]

46. Yvan-Charvet, L.; Pagler, T.; Gautier, E.L.; Avagyan, S.; Siry, R.L.; Han, S.; Welch, C.L.; Wang, N.; Randolph, G.J.; Snoeck, H.W.; et al. ATP-binding cassette transporters and HDL suppress hematopoietic stem cell proliferation. Science 2010, 328, 1689-1693. [CrossRef] [PubMed]

47. Fessler, M.B.; Parks, J.S. Intracellular lipid flux and membrane microdomains as organizing principles in inflammatory cell signaling. J. Immunol. 2011, 187, 1529-1535. [CrossRef]

48. Gupta, N.; DeFranco, A.L. Lipid rafts and B cell signaling. Semin Cell Dev. Biol. 2007, 18, 616-626. [CrossRef]

49. Kabouridis, P.S.; Jury, E.C. Lipid rafts and T-lymphocyte function: Implications for autoimmunity. FEBS Lett. 2008, 582, 3711-3718. [CrossRef]

50. Murphy, A.J.; Woollard, K.J.; Suhartoyo, A.; Stirzaker, R.A.; Shaw, J.; Sviridov, D.; Chin-Dusting, J.P. Neutrophil activation is attenuated by high-density lipoprotein and apolipoprotein A-I in in vitro and in vivo models of inflammation. Arterioscler. Thromb. Vasc. Biol. 2011, 31, 1333-1341. [CrossRef]

51. Wang, S.H.; Yuan, S.G.; Peng, D.Q.; Zhao, S.P. HDL and ApoA-I inhibit antigen presentation-mediated T cell activation by disrupting lipid rafts in antigen presenting cells. Atherosclerosis 2012, 225, 105-114. [CrossRef] [PubMed]

52. Kim, K.D.; Lim, H.Y.; Lee, H.G.; Yoon, D.Y.; Choe, Y.K.; Choi, I.; Paik, S.G.; Kim, Y.S.; Yang, Y.; Lim, J.S. Apolipoprotein A-I induces IL-10 and PGE2 production in human monocytes and inhibits dendritic cell differentiation and maturation. Biochem. Biophys. Res. Commun. 2005, 338, 1126-1136. [CrossRef] [PubMed]

53. Tiniakou, I.; Drakos, E.; Sinatkas, V.; Van Eck, M.; Zannis, V.I.; Boumpas, D.; Verginis, P.; Kardassis, D. High-density lipoprotein attenuates Th1 and Th17 autoimmune responses by modulating dendritic cell maturation and function. J. Immunol. 2015, 194, 4676-4687. [CrossRef] [PubMed]

54. De Nardo, D.; Labzin, L.I.; Kono, H.; Seki, R.; Schmidt, S.V.; Beyer, M.; Xu, D.; Zimmer, S.; Lahrmann, C.; Schildberg, F.A.; et al. High-density lipoprotein mediates anti-inflammatory reprogramming of macrophages via the transcriptional regulator ATF3. Nat. Immunol. 2014, 15, 152-160. [CrossRef] [PubMed]

55. Thacker, S.G.; Zarzour, A.; Chen, Y.; Alcicek, M.S.; Freeman, L.A.; Sviridov, D.O.; Demosky, S.J., Jr.; Remaley, A.T. High-density lipoprotein reduces inflammation from cholesterol crystals by inhibiting inflammasome activation. Immunology 2016, 149, 306-319. [CrossRef] [PubMed]

56. Tall, A.R.; Westerterp, M. Inflammasomes, neutrophil extracellular traps, and cholesterol. J. Lipid Res. 2019, 60, 721-727. [CrossRef] [PubMed]

57. Westerterp, M.; Fotakis, P.; Ouimet, M.; Bochem, A.E.; Zhang, H.; Molusky, M.M.; Wang, W.; Abramowicz, S.; La Bastide-van Gemert, S.; Wang, N.; et al. Cholesterol Efflux Pathways Suppress Inflammasome Activation, NETosis, and Atherogenesis. Circulation 2018, 138, 898-912. [CrossRef] [PubMed]

58. Westerterp, M.; Gautier, E.L.; Ganda, A.; Molusky, M.M.; Wang, W.; Fotakis, P.; Wang, N.; Randolph, G.J.; D'Agati, V.D.; Yvan-Charvet, L.; et al. Cholesterol Accumulation in Dendritic Cells Links the Inflammasome to Acquired Immunity. Cell Metab. 2017, 25, 1294-1304. [CrossRef] 
59. Wilhelm, A.J.; Zabalawi, M.; Owen, J.S.; Shah, D.; Grayson, J.M.; Major, A.S.; Bhat, S.; Gibbs, D.P., Jr.; Thomas, M.J.; Sorci-Thomas, M.G. Apolipoprotein A-I modulates regulatory T cells in autoimmune LDLr-/-, ApoA-I-/- mice. J. Biol. Chem. 2010, 285, 36158-36169. [CrossRef]

60. Castella, B.; Kopecka, J.; Sciancalepore, P.; Mandili, G.; Foglietta, M.; Mitro, N.; Caruso, D.; Novelli, F.; Riganti, C.; Massaia, M. The ATP-binding cassette transporter A1 regulates phosphoantigen release and Vgamma9Vdelta2 T cell activation by dendritic cells. Nat. Commun. 2017, 8, 15663. [CrossRef]

61. Gkouskou, K.K.; Ioannou, M.; Pavlopoulos, G.A.; Georgila, K.; Siganou, A.; Nikolaidis, G.; Kanellis, D.C.; Moore, S.; Papadakis, K.A.; Kardassis, D.; et al. Apolipoprotein A-I inhibits experimental colitis and colitis-propelled carcinogenesis. Oncogene 2016, 35, 2496-2505. [CrossRef] [PubMed]

62. Murano, T.; Najibi, M.; Paulus, G.L.C.; Adiliaghdam, F.; Valencia-Guerrero, A.; Selig, M.; Wang, X.; Jeffrey, K.; Xavier, R.J.; Lassen, K.G.; et al. Transcription factor TFEB cell-autonomously modulates susceptibility to intestinal epithelial cell injury in vivo. Sci. Rep. 2017, 7, 13938. [CrossRef] [PubMed]

63. Khera, A.V.; Cuchel, M.; De la Llera-Moya, M.; Rodrigues, A.; Burke, M.F.; Jafri, K.; French, B.C.; Phillips, J.A.; Mucksavage, M.L.; Wilensky, R.L.; et al. Cholesterol efflux capacity, high-density lipoprotein function, and atherosclerosis. N. Engl. J. Med. 2011, 364, 127-135. [CrossRef] [PubMed]

64. Pan, B.; Ren, H.; Lv, X.; Zhao, Y.; Yu, B.; He, Y.; Ma, Y.; Niu, C.; Kong, J.; Yu, F.; et al. Hypochlorite-induced oxidative stress elevates the capability of HDL in promoting breast cancer metastasis. J. Transl. Med. 2012, 10, 65. [CrossRef] [PubMed]

65. Pirillo, A.; Catapano, A.L.; Norata, G.D. Biological Consequences of Dysfunctional HDL. Curr. Med. Chem. 2019, 26, 1644-1664. [CrossRef] [PubMed]

66. Huang, Y.; DiDonato, J.A.; Levison, B.S.; Schmitt, D.; Li, L.; Wu, Y.; Buffa, J.; Kim, T.; Gerstenecker, G.S.; $\mathrm{Gu}, \mathrm{X} . ;$ et al. An abundant dysfunctional apolipoprotein A1 in human atheroma. Nat. Med. 2014, 20, 193-203. [CrossRef] [PubMed]

67. Jiang, Y.; Sun, A.; Zhao, Y.; Ying, W.; Sun, H.; Yang, X.; Xing, B.; Sun, W.; Ren, L.; Hu, B.; et al. Proteomics identifies new therapeutic targets of early-stage hepatocellular carcinoma. Nature 2019, 567, 257-261. [CrossRef] [PubMed]

68. Ai, J.; Tan, Y.; Ying, W.; Hong, Y.; Liu, S.; Wu, M.; Qian, X.; Wang, H. Proteome analysis of hepatocellular carcinoma by laser capture microdissection. Proteomics 2006, 6, 538-546. [CrossRef]

69. Mustafa, M.G.; Petersen, J.R.; Ju, H.; Cicalese, L.; Snyder, N.; Haidacher, S.J.; Denner, L.; Elferink, C. Biomarker discovery for early detection of hepatocellular carcinoma in hepatitis C-infected patients. Mol. Cell. Proteom. 2013, 12, 3640-3652. [CrossRef]

70. Steel, L.F.; Shumpert, D.; Trotter, M.; Seeholzer, S.H.; Evans, A.A.; London, W.T.; Dwek, R.; Block, T.M. A strategy for the comparative analysis of serum proteomes for the discovery of biomarkers for hepatocellular carcinoma. Proteomics 2003, 3, 601-609. [CrossRef]

71. Jiang, J.; Nilsson-Ehle, P.; Xu, N. Influence of liver cancer on lipid and lipoprotein metabolism. Lipids Health Dis. 2006, 5, 4. [CrossRef] [PubMed]

72. Ahn, J.; Lim, U.; Weinstein, S.J.; Schatzkin, A.; Hayes, R.B.; Virtamo, J.; Albanes, D. Prediagnostic total and high-density lipoprotein cholesterol and risk of cancer. Cancer Epidemiol. Biomark. Prev. 2009, 18, 2814-2821. [CrossRef] [PubMed]

73. Chandler, P.D.; Song, Y.; Lin, J.; Zhang, S.; Sesso, H.D.; Mora, S.; Giovannucci, E.L.; Rexrode, K.E.; Moorthy, M.V.; Li, C.; et al. Lipid biomarkers and long-term risk of cancer in the Women's Health Study. Am. J. Clin. Nutr. 2016, 103, 1397-1407. [CrossRef] [PubMed]

74. Borgquist, S.; Butt, T.; Almgren, P.; Shiffman, D.; Stocks, T.; Orho-Melander, M.; Manjer, J.; Melander, O. Apolipoproteins, lipids and risk of cancer. Int. J. Cancer 2016, 138, 2648-2656. [CrossRef] [PubMed]

75. Bayerdorffer, E.; Mannes, G.A.; Richter, W.O.; Ochsenkuhn, T.; Seeholzer, G.; Kopcke, W.; Wiebecke, B.; Paumgartner, G. Decreased high-density lipoprotein cholesterol and increased low-density cholesterol levels in patients with colorectal adenomas. Ann. Intern. Med. 1993, 118, 481-487. [CrossRef]

76. Jung, Y.S.; Ryu, S.; Chang, Y.; Yun, K.E.; Park, J.H.; Kim, H.J.; Cho, Y.K.; Sohn, C.I.; Jeon, W.K.; Kim, B.I.; et al. Associations Between Parameters of Glucose and Lipid Metabolism and Risk of Colorectal Neoplasm. Dig. Dis. Sci. 2015, 60, 2996-3004. [CrossRef] [PubMed]

77. Alford, S.H.; Divine, G.; Chao, C.; Habel, L.A.; Janakiraman, N.; Wang, Y.; Feigelson, H.S.; Scholes, D.; Roblin, D.; Epstein, M.M.; et al. Serum cholesterol trajectories in the 10 years prior to lymphoma diagnosis. Cancer Causes Control. 2018, 29, 143-156. [CrossRef] 
78. Van Hemelrijck, M.; Walldius, G.; Jungner, I.; Hammar, N.; Garmo, H.; Binda, E.; Hayday, A.; Lambe, M.; Holmberg, L. Low levels of apolipoprotein A-I and HDL are associated with risk of prostate cancer in the Swedish AMORIS study. Cancer Causes Control. 2011, 22, 1011-1019. [CrossRef] [PubMed]

79. Gourin, C.G.; Zhi, W.; Adam, B.L. Proteomic identification of serum biomarkers for head and neck cancer surveillance. Laryngoscope 2009, 119, 1291-1302. [CrossRef] [PubMed]

80. Chang, H.; Wei, J.W.; Chen, K.; Zhang, S.; Han, F.; Lu, L.X.; Xiao, W.W.; Gao, Y.H. Apolipoprotein A-I Is a Prognosticator of Nasopharyngeal Carcinoma in the Era of Intensity-modulated Radiotherapy. J. Cancer 2018, 9, 702-710. [CrossRef] [PubMed]

81. Jiang, R.; Yang, Z.H.; Luo, D.H.; Guo, L.; Sun, R.; Chen, Q.Y.; Huang, P.Y.; Qiu, F.; Zou, X.; Cao, K.J.; et al. Elevated apolipoprotein A-I levels are associated with favorable prognosis in metastatic nasopharyngeal carcinoma. Med Oncol. 2014, 31, 80. [CrossRef] [PubMed]

82. Luo, X.L.; Zhong, G.Z.; Hu, L.Y.; Chen, J.; Liang, Y.; Chen, Q.Y.; Liu, Q.; Rao, H.L.; Chen, K.L.; Cai, Q.Q. Serum apolipoprotein A-I is a novel prognostic indicator for non-metastatic nasopharyngeal carcinoma. Oncotarget 2015, 6, 44037-44048. [CrossRef]

83. Zablocka-Slowinska, K.; Placzkowska, S.; Skorska, K.; Prescha, A.; Pawelczyk, K.; Porebska, I.; Kosacka, M.; Grajeta, H. Oxidative stress in lung cancer patients is associated with altered serum markers of lipid metabolism. PLoS ONE 2019, 14, e0215246. [CrossRef]

84. Chang, Y.K.; Lai, Y.H.; Chu, Y.; Lee, M.C.; Huang, C.Y.; Wu, S. Haptoglobin is a serological biomarker for adenocarcinoma lung cancer by using the ProteomeLab PF2D combined with mass spectrometry. Am. J. Cancer Res. 2016, 6, 1828-1836. [PubMed]

85. Cheng, T.; Dai, X.; Zhou, D.L.; Lv, Y.; Miao, L.Y. Correlation of apolipoprotein A-I kinetics with survival and response to first-line platinum-based chemotherapy in advanced non-small cell lung cancer. Med. Oncol. 2015, 32, 407. [CrossRef]

86. Shi, H.; Huang, H.; Pu, J.; Shi, D.; Ning, Y.; Dong, Y.; Han, Y.; Zarogoulidis, P.; Bai, C. Decreased pretherapy serum apolipoprotein A-I is associated with extent of metastasis and poor prognosis of non-small-cell lung cancer. Onco Targets Ther. 2018, 11, 6995-7003. [CrossRef] [PubMed]

87. Marchi, N.; Mazzone, P.; Fazio, V.; Mekhail, T.; Masaryk, T.; Janigro, D. ProApolipoprotein A1: A serum marker of brain metastases in lung cancer patients. Cancer 2008, 112, 1313-1324. [CrossRef] [PubMed]

88. Li, C.; Xia, G.; Jianqing, Z.; Mei, Y.; Ge, B.; Li, Z. Serum differential protein identification of Xinjiang Kazakh esophageal cancer patients based on the two-dimensional liquid-phase chromatography and LTQ MS. Mol. Biol. Rep. 2014, 41, 2893-2905. [CrossRef]

89. Wang, X.P.; Li, X.H.; Zhang, L.; Lin, J.H.; Huang, H.; Kang, T.; Mao, M.J.; Chen, H.; Zheng, X. High level of serum apolipoprotein A-I is a favorable prognostic factor for overall survival in esophageal squamous cell carcinoma. BMC Cancer 2016, 16, 516. [CrossRef] [PubMed]

90. Shi, F.; Wu, H.; Qu, K.; Sun, Q.; Li, F.; Shi, C.; Li, Y.; Xiong, X.; Qin, Q.; Yu, T.; et al. Identification of serum proteins AHSG, FGA and APOA-I as diagnostic biomarkers for gastric cancer. Clin. Proteom. 2018, 15, 18. [CrossRef] [PubMed]

91. Wu, J.Y.; Cheng, C.C.; Wang, J.Y.; Wu, D.C.; Hsieh, J.S.; Lee, S.C.; Wang, W.M. Discovery of tumor markers for gastric cancer by proteomics. PLoS ONE 2014, 9, e84158. [CrossRef] [PubMed]

92. Lim, L.C.; Looi, M.L.; Zakaria, S.Z.; Sagap, I.; Rose, I.M.; Chin, S.F.; Jamal, R. Identification of Differentially Expressed Proteins in the Serum of Colorectal Cancer Patients Using 2D-DIGE Proteomics Analysis. Pathol. Oncol. Res. 2016, 22, 169-177. [CrossRef] [PubMed]

93. Van Duijnhoven, F.J.; Bueno-De-Mesquita, H.B.; Calligaro, M.; Jenab, M.; Pischon, T.; Jansen, E.H.; Frohlich, J.; Ayyobi, A.; Overvad, K.; Toft-Petersen, A.P.; et al. Blood lipid and lipoprotein concentrations and colorectal cancer risk in the European Prospective Investigation into Cancer and Nutrition. Gut 2011, 60, 1094-1102. [CrossRef] [PubMed]

94. Zhang, X.; Zhao, X.W.; Liu, D.B.; Han, C.Z.; Du, L.L.; Jing, J.X.; Wang, Y. Lipid levels in serum and cancerous tissues of colorectal cancer patients. World J. Gastroenterol. 2014, 20, 8646-8652. [CrossRef] [PubMed]

95. Sirnio, P.; Vayrynen, J.P.; Klintrup, K.; Makela, J.; Makinen, M.J.; Karttunen, T.J.; Tuomisto, A. Decreased serum apolipoprotein A1 levels are associated with poor survival and systemic inflammatory response in colorectal cancer. Sci. Rep. 2017, 7, 5374. [CrossRef] [PubMed] 
96. Sayagues, J.M.; Corchete, L.A.; Gutierrez, M.L.; Sarasquete, M.E.; Del Mar Abad, M.; Bengoechea, O.; Ferminan, E.; Anduaga, M.F.; Del Carmen, S.; Iglesias, M.; et al. Genomic characterization of liver metastases from colorectal cancer patients. Oncotarget 2016, 7, 72908-72922. [CrossRef] [PubMed]

97. Sakaguchi, Y.; Yamamichi, N.; Tomida, S.; Takeuchi, C.; Kageyama-Yahara, N.; Takahashi, Y.; Shiogama, K.; Inada, K.I.; Ichinose, M.; Fujishiro, M.; et al. Identification of marker genes and pathways specific to precancerous duodenal adenomas and early stage adenocarcinomas. J. Gastroenterol. 2018, 54, 131-140. [CrossRef]

98. Fye, H.K.; Wright-Drakesmith, C.; Kramer, H.B.; Camey, S.; Nogueira da Costa, A.; Jeng, A.; Bah, A.; Kirk, G.D.; Sharif, M.I.; Ladep, N.G.; et al. Protein profiling in hepatocellular carcinoma by label-free quantitative proteomics in two west African populations. PLoS ONE 2013, 8, e68381. [CrossRef]

99. Qin, X.; Chen, Q.; Sun, C.; Wang, C.; Peng, Q.; Xie, L.; Liu, Y.; Li, S. High-throughput screening of tumor metastatic-related differential glycoprotein in hepatocellular carcinoma by iTRAQ combines lectin-related techniques. Med Oncol. 2013, 30, 420. [CrossRef]

100. Ma, X.L.; Gao, X.H.; Gong, Z.J.; Wu, J.; Tian, L.; Zhang, C.Y.; Zhou, Y.; Sun, Y.F.; Hu, B.; Qiu, S.J.; et al. Apolipoprotein A1: A novel serum biomarker for predicting the prognosis of hepatocellular carcinoma after curative resection. Oncotarget 2016, 7, 70654-70668. [CrossRef]

101. Mao, M.; Wang, X.; Sheng, H.; Liu, Y.; Zhang, L.; Dai, S.; Chi, P.D. A novel score based on serum apolipoprotein A-1 and C-reactive protein is a prognostic biomarker in hepatocellular carcinoma patients. BMC Cancer 2018, 18, 1178. [CrossRef] [PubMed]

102. Xu, X.; Wei, X.; Ling, Q.; Cheng, J.; Zhou, B.; Xie, H.; Zhou, L.; Zheng, S. Identification of two portal vein tumor thrombosis associated proteins in hepatocellular carcinoma: Protein disulfide-isomerase A6 and apolipoprotein A-I. J. Gastroenterol. Hepatol. 2011, 26, 1787-1794. [CrossRef] [PubMed]

103. Zuo, M.; Rashid, A.; Wang, Y.; Jain, A.; Li, D.; Behari, A.; Kapoor, V.K.; Koay, E.J.; Chang, P.; Vauthey, J.N.; et al. RNA sequencing-based analysis of gallbladder cancer reveals the importance of the liver $\mathrm{X}$ receptor and lipid metabolism in gallbladder cancer. Oncotarget 2016, 7, 35302-35312. [CrossRef] [PubMed]

104. Ehmann, M.; Felix, K.; Hartmann, D.; Schnolzer, M.; Nees, M.; Vorderwulbecke, S.; Bogumil, R.; Buchler, M.W.; Friess, H. Identification of potential markers for the detection of pancreatic cancer through comparative serum protein expression profiling. Pancreas 2007, 34, 205-214. [CrossRef] [PubMed]

105. Liu, X.; Zheng, W.; Wang, W.; Shen, H.; Liu, L.; Lou, W.; Wang, X.; Yang, P. A new panel of pancreatic cancer biomarkers discovered using a mass spectrometry-based pipeline. Br. J. Cancer 2017, 117, 1846-1854. [CrossRef] [PubMed]

106. Chung, L.; Moore, K.; Phillips, L.; Boyle, F.M.; Marsh, D.J.; Baxter, R.C. Novel serum protein biomarker panel revealed by mass spectrometry and its prognostic value in breast cancer. Breast Cancer Res. 2014, 16, R63. [CrossRef] [PubMed]

107. Goncalves, A.; Esterni, B.; Bertucci, F.; Sauvan, R.; Chabannon, C.; Cubizolles, M.; Bardou, V.J.; Houvenaegel, G.; Jacquemier, J.; Granjeaud, S.; et al. Postoperative serum proteomic profiles may predict metastatic relapse in high-risk primary breast cancer patients receiving adjuvant chemotherapy. Oncogene 2006, 25, 981-989. [CrossRef] [PubMed]

108. His, M.; Zelek, L.; Deschasaux, M.; Pouchieu, C.; Kesse-Guyot, E.; Hercberg, S.; Galan, P.; Latino-Martel, P.; Blacher, J.; Touvier, M. Prospective associations between serum biomarkers of lipid metabolism and overall, breast and prostate cancer risk. Eur. J. Epidemiol. 2014, 29, 119-132. [CrossRef]

109. Lin, X.; Hong, S.; Huang, J.; Chen, Y.; Chen, Y.; Wu, Z. Plasma apolipoprotein A1 levels at diagnosis are independent prognostic factors in invasive ductal breast cancer. Discov. Med. 2017, 23, 247-258.

110. Hamrita, B.; Ben Nasr, H.; Gabbouj, S.; Bouaouina, N.; Chouchane, L.; Chahed, K. Apolipoprotein A1 -75 G/A and $+83 \mathrm{C} / \mathrm{T}$ polymorphisms: Susceptibility and prognostic implications in breast cancer. Mol. Biol. Rep. 2011, 38, 1637-1643. [CrossRef]

111. Hsu, M.C.; Lee, K.T.; Hsiao, W.C.; Wu, C.H.; Sun, H.Y.; Lin, I.L.; Young, K.C. The dyslipidemia-associated $\mathrm{SNP}$ on the APOA1/C3/A5 gene cluster predicts post-surgery poor outcome in Taiwanese breast cancer patients: A 10-year follow-up study. BMC Cancer 2013, 13, 330. [CrossRef] [PubMed]

112. Martin, L.J.; Melnichouk, O.; Huszti, E.; Connelly, P.W.; Greenberg, C.V.; Minkin, S.; Boyd, N.F. Serum lipids, lipoproteins, and risk of breast cancer: A nested case-control study using multiple time points. J. Natl. Cancer Inst. 2015, 107, 32. [CrossRef] [PubMed] 
113. Zografos, E.; Anagnostopoulos, A.K.; Papadopoulou, A.; Legaki, E.; Zagouri, F.; Marinos, E.; Tsangaris, G.T.; Gazouli, M. Serum Proteomic Signatures of Male Breast Cancer. Cancer Genom. Proteom. 2019, 16, 129-137. [CrossRef] [PubMed]

114. Cine, N.; Baykal, A.T.; Sunnetci, D.; Canturk, Z.; Serhatli, M.; Savli, H. Identification of ApoA1, HPX and POTEE genes by omic analysis in breast cancer. Oncol. Rep. 2014, 32, 1078-1086. [CrossRef] [PubMed]

115. Liu, J.X.; Yuan, Q.; Min, Y.L.; He, Y.; Xu, Q.H.; Li, B.; Shi, W.Q.; Lin, Q.; Li, Q.H.; Zhu, P.W.; et al. Apolipoprotein A1 and B as risk factors for development of intraocular metastasis in patients with breast cancer. Cancer Manag. Res. 2019, 11, 2881-2888. [CrossRef]

116. Pendharkar, N.; Gajbhiye, A.; Taunk, K.; RoyChoudhury, S.; Dhali, S.; Seal, S.; Mane, A.; Abhang, S.; Santra, M.K.; Chaudhury, K.; et al. Quantitative tissue proteomic investigation of invasive ductal carcinoma of breast with luminal B HER2 positive and HER2 enriched subtypes towards potential diagnostic and therapeutic biomarkers. J. Proteom. 2016, 132, 112-130. [CrossRef]

117. Clarke, C.H.; Yip, C.; Badgwell, D.; Fung, E.T.; Coombes, K.R.; Zhang, Z.; Lu, K.H.; Bast, R.C., Jr. Proteomic biomarkers apolipoprotein A1, truncated transthyretin and connective tissue activating protein III enhance the sensitivity of CA125 for detecting early stage epithelial ovarian cancer. Gynecol. Oncol. 2011, 122, 548-553. [CrossRef]

118. Kozak, K.R.; Amneus, M.W.; Pusey, S.M.; Su, F.; Luong, M.N.; Luong, S.A.; Reddy, S.T.; Farias-Eisner, R. Identification of biomarkers for ovarian cancer using strong anion-exchange ProteinChips: Potential use in diagnosis and prognosis. Proc. Natl. Acad. Sci. USA 2003, 100, 12343-12348. [CrossRef]

119. Kozak, K.R.; Su, F.; Whitelegge, J.P.; Faull, K.; Reddy, S.; Farias-Eisner, R. Characterization of serum biomarkers for detection of early stage ovarian cancer. Proteomics 2005, 5, 4589-4596. [CrossRef]

120. Wegdam, W.; Argmann, C.A.; Kramer, G.; Vissers, J.P.; Buist, M.R.; Kenter, G.G.; Aerts, J.M.; Meijer, D.; Moerland, P.D. Label-free LC-MSe in tissue and serum reveals protein networks underlying differences between benign and malignant serous ovarian tumors. PLoS ONE 2014, 9, e108046. [CrossRef]

121. Cruz, I.N.; Coley, H.M.; Kramer, H.B.; Madhuri, T.K.; Safuwan, N.A.; Angelino, A.R.; Yang, M. Proteomics Analysis of Ovarian Cancer Cell Lines and Tissues Reveals Drug Resistance-associated Proteins. Cancer Genom. Proteom. 2017, 14, 35-51. [CrossRef] [PubMed]

122. Tuft Stavnes, H.; Nymoen, D.A.; Hetland Falkenthal, T.E.; Kaern, J.; Trope, C.G.; Davidson, B. APOA1 mRNA expression in ovarian serous carcinoma effusions is a marker of longer survival. Am. J. Clin. Pathol. 2014, 142, 51-57. [CrossRef] [PubMed]

123. Farias-Eisner, G.; Su, F.; Robbins, T.; Kotlerman, J.; Reddy, S.; Farias-Eisner, R. Validation of serum biomarkers for detection of early- and late-stage endometrial cancer. Am. J. Obstet. Gynecol. 2010, 202, 73. [CrossRef] [PubMed]

124. Rizner, T.L. Discovery of biomarkers for endometrial cancer: Current status and prospects. Expert Rev. Mol. Diagn. 2016, 16, 1315-1336. [CrossRef] [PubMed]

125. Takano, M.; Kikuchi, Y.; Asakawa, T.; Goto, T.; Kita, T.; Kudoh, K.; Kigawa, J.; Sakuragi, N.; Sakamoto, M.; Sugiyama, T.; et al. Identification of potential serum markers for endometrial cancer using protein expression profiling. J. Cancer Res. Clin. Oncol. 2010, 136, 475-481. [CrossRef]

126. Chen, Y.; Xiong, X.; Wang, Y.; Zhao, J.; Shi, H.; Zhang, H.; Wang, Y.; Wei, Y.; Xue, W.; Zhang, J. Proteomic Screening for Serum Biomarkers for Cervical Cancer and Their Clinical Significance. Med. Sci. Monit. Int. Med. J. Exp. Clin. Res. 2019, 25, 288-297. [CrossRef] [PubMed]

127. Guo, X.; Hao, Y.; Kamilijiang, M.; Hasimu, A.; Yuan, J.; Wu, G.; Reyimu, H.; Kadeer, N.; Abudula, A. Potential predictive plasma biomarkers for cervical cancer by 2D-DIGE proteomics and Ingenuity Pathway Analysis. Tumour Biol. 2015, 36, 1711-1720. [CrossRef]

128. Alaiya, A.A.; Al-Mohanna, M.; Aslam, M.; Shinwari, Z.; Al-Mansouri, L.; Al-Rodayan, M.; Al-Eid, M.; Ahmad, I.; Hanash, K.; Tulbah, A.; et al. Proteomics-based signature for human benign prostate hyperplasia and prostate adenocarcinoma. Int. J. Oncol. 2011, 38, 1047-1057. [CrossRef]

129. Davalieva, K.; Kiprijanovska, S.; Komina, S.; Petrusevska, G.; Zografska, N.C.; Polenakovic, M. Proteomics analysis of urine reveals acute phase response proteins as candidate diagnostic biomarkers for prostate cancer. Proteome Sci. 2015, 13, 2. [CrossRef]

130. Chen, C.L.; Lin, T.S.; Tsai, C.H.; Wu, C.C.; Chung, T.; Chien, K.Y.; Wu, M.; Chang, Y.S.; Yu, J.S.; Chen, Y.T. Identification of potential bladder cancer markers in urine by abundant-protein depletion coupled with quantitative proteomics. J. Proteom. 2013, 85, 28-43. [CrossRef] 
131. Chen, Y.T.; Chen, C.L.; Chen, H.W.; Chung, T.; Wu, C.C.; Chen, C.D.; Hsu, C.W.; Chen, M.C.; Tsui, K.H.; Chang, P.L.; et al. Discovery of novel bladder cancer biomarkers by comparative urine proteomics using iTRAQ technology. J. Proteome Res. 2010, 9, 5803-5815. [CrossRef] [PubMed]

132. Li, H.; Li, C.; Wu, H.; Zhang, T.; Wang, J.; Wang, S.; Chang, J. Identification of Apo-A1 as a biomarker for early diagnosis of bladder transitional cell carcinoma. Proteome Sci. 2011, 9, 21. [CrossRef] [PubMed]

133. Shang, Z.; Wang, J.; Wang, X.; Yan, H.; Cui, B.; Jia, C.; Wang, Q.; Cui, X.; Li, J.; Ou, T. Preoperative serum apolipoprotein A-I levels predict long-term survival in non-muscle-invasive bladder cancer patients. Cancer Manag. Res. 2018, 10, 1177-1190. [CrossRef] [PubMed]

134. Chinello, C.; Stella, M.; Piga, I.; Smith, A.J.; Bovo, G.; Varallo, M.; Ivanova, M.; Denti, V.; Grasso, M.; Grasso, A.; et al. Proteomics of liquid biopsies: Depicting RCC infiltration into the renal vein by MS analysis of urine and plasma. J. Proteom. 2019, 191, 29-37. [CrossRef] [PubMed]

135. Guo, S.; He, X.; Chen, Q.; Yang, G.; Yao, K.; Dong, P.; Ye, Y.; Chen, D.; Zhang, Z.; Qin, Z.; et al. The Effect of Preoperative Apolipoprotein A-I on the Prognosis of Surgical Renal Cell Carcinoma: A Retrospective Large Sample Study. Medicine 2016, 95, e3147. [CrossRef] [PubMed]

136. Halton, J.M.; Nazir, D.J.; McQueen, M.J.; Barr, R.D. Blood lipid profiles in children with acute lymphoblastic leukemia. Cancer 1998, 83, 379-384. [CrossRef]

137. Scribano, D.; Baroni, S.; Pagano, L.; Zuppi, C.; Leone, G.; Giardina, B. Return to normal values of lipid pattern after effective chemotherapy in acute lymphoblastic leukemia. Haematologica 1996, 81, 343-345.

138. Egler, R.A.; Li, Y.; Dang, T.A.; Peters, T.L.; Leung, E.; Huang, S.; Russell, H.V.; Liu, H.; Man, T.K. An integrated proteomic approach to identifying circulating biomarkers in high-risk neuroblastoma and their potential in relapse monitoring. Proteom. Clin. Appl. 2011, 5, 532-541. [CrossRef]

139. Naru, J.; Aggarwal, R.; Mohanty, A.K.; Singh, U.; Bansal, D.; Kakkar, N.; Agnihotri, N. Identification of differentially expressed proteins in retinoblastoma tumors using mass spectrometry-based comparative proteomic approach. J. Proteom. 2017, 159, 77-91. [CrossRef]

140. Muntoni, S.; Atzori, L.; Mereu, R.; Satta, G.; Macis, M.D.; Congia, M.; Tedde, A.; Desogus, A.; Muntoni, S. Serum lipoproteins and cancer. Nutr. Metab. Cardiovasc. Dis. 2009, 19, 218-225. [CrossRef]

141. Li, X.; Liu, Z.L.; Wu, Y.T.; Wu, H.; Dai, W.; Arshad, B.; Xu, Z.; Li, H.; Wu, K.N.; Kong, L.Q. Status of lipid and lipoprotein in female breast cancer patients at initial diagnosis and during chemotherapy. Lipids Health Dis. 2018, 17, 91. [CrossRef] [PubMed]

142. Wu, J.; Zhang, C.; Zhang, G.; Wang, Y.; Zhang, Z.; Su, W.; Lyu, J. Association Between Pretreatment Serum Apolipoprotein A1 and Prognosis of Solid Tumors in Chinese Population: A Systematic Review and Meta-Analysis. Cell. Physiol. Biochem. 2018, 51, 575-588. [CrossRef] [PubMed]

143. Zhang, Y.; Yang, X. Prognostic Significance of Pretreatment Apolipoprotein A-I as a Noninvasive Biomarker in Cancer Survivors: A Meta-Analysis. Dis. Markers 2018, 2018, 1034037. [CrossRef] [PubMed]

144. Wang, Y.; Wang, Z.Q.; Wang, F.H.; Lei, X.F.; Yan, S.M.; Wang, D.S.; Zhang, F.; Xu, R.H.; Wang, L.Y.; Li, Y.H. Predictive value of chemotherapy-related high-density lipoprotein cholesterol (HDL) elevation in patients with colorectal cancer receiving adjuvant chemotherapy: An exploratory analysis of 851 cases. Oncotarget 2016, 7, 57290-57300. [CrossRef] [PubMed]

145. Cortesi, L.; Barchetti, A.; De Matteis, E.; Rossi, E.; Della Casa, L.; Marcheselli, L.; Tazzioli, G.; Lazzaretti, M.G.; Ficarra, G.; Federico, M.; et al. Identification of protein clusters predictive of response to chemotherapy in breast cancer patients. J. Proteome Res. 2009, 8, 4916-4933. [CrossRef] [PubMed]

146. Zhang, J.; Cai, Y.; Hu, H.; Lan, P.; Wang, L.; Huang, M.; Kang, L.; Wu, X.; Wang, H.; Ling, J.; et al. Nomogram basing pre-treatment parameters predicting early response for locally advanced rectal cancer with neoadjuvant chemotherapy alone: A subgroup efficacy analysis of FOWARC study. Oncotarget 2016, 7, 5053-5062. [CrossRef] [PubMed]

147. Walter, S.; Weinschenk, T.; Stenzl, A.; Zdrojowy, R.; Pluzanska, A.; Szczylik, C.; Staehler, M.; Brugger, W.; Dietrich, P.Y.; Mendrzyk, R.; et al. Multipeptide immune response to cancer vaccine IMA901 after single-dose cyclophosphamide associates with longer patient survival. Nat. Med. 2012, 18, 1254-1261. [CrossRef] [PubMed]

148. Zhang, T.; Guo, J.; Gu, J.; Wang, Z.; Wang, G.; Li, H.; Wang, J. Identifying the key genes and microRNAs in colorectal cancer liver metastasis by bioinformatics analysis and in vitro experiments. Oncol. Rep. 2019, 41, 279-291. [CrossRef] [PubMed] 
149. Danilo, C.; Gutierrez-Pajares, J.L.; Mainieri, M.A.; Mercier, I.; Lisanti, M.P.; Frank, P.G. Scavenger receptor class B type I regulates cellular cholesterol metabolism and cell signaling associated with breast cancer development. Breast Cancer Res. 2013, 15, R87. [CrossRef] [PubMed]

150. Gutierrez-Pajares, J.L.; Ben Hassen, C.; Chevalier, S.; Frank, P.G. SR-BI: Linking Cholesterol and Lipoprotein Metabolism with Breast and Prostate Cancer. Front. Pharmacol. 2016, 7, 338. [CrossRef]

151. Zheng, Y.; Liu, Y.; Jin, H.; Pan, S.; Qian, Y.; Huang, C.; Zeng, Y.; Luo, Q.; Zeng, M.; Zhang, Z. Scavenger receptor B1 is a potential biomarker of human nasopharyngeal carcinoma and its growth is inhibited by HDL-mimetic nanoparticles. Theranostics 2013, 3, 477-486. [CrossRef] [PubMed]

152. Su, F.; Kozak, K.R.; Imaizumi, S.; Gao, F.; Amneus, M.W.; Grijalva, V.; Ng, C.; Wagner, A.; Hough, G.; Farias-Eisner, G.; et al. Apolipoprotein A-I (apoA-I) and apoA-I mimetic peptides inhibit tumor development in a mouse model of ovarian cancer. Proc. Natl. Acad. Sci. USA 2010, 107, 19997-20002. [CrossRef] [PubMed]

153. Ganapathy, E.; Su, F.; Meriwether, D.; Devarajan, A.; Grijalva, V.; Gao, F.; Chattopadhyay, A.; Anantharamaiah, G.M.; Navab, M.; Fogelman, A.M.; et al. D-4F, an apoA-I mimetic peptide, inhibits proliferation and tumorigenicity of epithelial ovarian cancer cells by upregulating the antioxidant enzyme MnSOD. Int. J. Cancer 2012, 130, 1071-1081. [CrossRef] [PubMed]

154. Marinho, A.T.; Lu, H.; Pereira, S.A.; Monteiro, E.; Gabra, H.; Recchi, C. Anti-tumorigenic and Platinum-Sensitizing Effects of Apolipoprotein A1 and Apolipoprotein A1 Mimetic Peptides in Ovarian Cancer. Front. Pharmacol. 2018, 9, 1524. [CrossRef] [PubMed]

155. Gao, F.; Vasquez, S.X.; Su, F.; Roberts, S.; Shah, N.; Grijalva, V.; Imaizumi, S.; Chattopadhyay, A.; Ganapathy, E.; Meriwether, D.; et al. L-5F, an apolipoprotein A-I mimetic, inhibits tumor angiogenesis by suppressing VEGF/basic FGF signaling pathways. Integr. Biol. 2011, 3, 479-489. [CrossRef] [PubMed]

156. Gao, F.; Chattopadhyay, A.; Navab, M.; Grijalva, V.; Su, F.; Fogelman, A.M.; Reddy, S.T.; Farias-Eisner, R. Apolipoprotein A-I mimetic peptides inhibit expression and activity of hypoxia-inducible factor-1alpha in human ovarian cancer cell lines and a mouse ovarian cancer model. J. Pharmacol. Exp. Ther. 2012, 342, 255-262. [CrossRef] [PubMed]

157. Aguirre-Portoles, C.; Feliu, J.; Reglero, G.; Ramirez de Molina, A. ABCA1 overexpression worsens colorectal cancer prognosis by facilitating tumour growth and caveolin-1-dependent invasiveness, and these effects can be ameliorated using the BET inhibitor apabetalone. Mol. Oncol. 2018, 12, 1735-1752. [CrossRef]

158. Su, F.; Grijalva, V.; Navab, K.; Ganapathy, E.; Meriwether, D.; Imaizumi, S.; Navab, M.; Fogelman, A.M.; Reddy, S.T.; Farias-Eisner, R. HDL mimetics inhibit tumor development in both induced and spontaneous mouse models of colon cancer. Mol. Cancer Ther. 2012, 11, 1311-1319. [CrossRef]

159. Cedo, L.; Garcia-Leon, A.; Baila-Rueda, L.; Santos, D.; Grijalva, V.; Martinez-Cignoni, M.R.; Carbo, J.M.; Metso, J.; Lopez-Vilaro, L.; Zorzano, A.; et al. ApoA-I mimetic administration, but not increased apoA-I-containing HDL, inhibits tumour growth in a mouse model of inherited breast cancer. Sci. Rep. 2016, 6, 36387. [CrossRef]

160. Peng, M.; Zhang, Q.; Cheng, Y.; Fu, S.; Yang, H.; Guo, X.; Zhang, J.; Wang, L.; Zhang, L.; Xue, Z.; et al. Apolipoprotein A-I mimetic peptide $4 \mathrm{~F}$ suppresses tumor-associated macrophages and pancreatic cancer progression. Oncotarget 2017, 8, 99693-99706. [CrossRef]

161. Zamanian-Daryoush, M.; Lindner, D.; Tallant, T.C.; Wang, Z.; Buffa, J.; Klipfell, E.; Parker, Y.; Hatala, D.; Parsons-Wingerter, P.; Rayman, P.; et al. The cardioprotective protein apolipoprotein A1 promotes potent anti-tumorigenic effects. J. Biol. Chem. 2013, 288, 21237-21252. [CrossRef] [PubMed]

162. Chattopadhyay, A.; Yang, X.; Mukherjee, P.; Sulaiman, D.; Fogelman, H.R.; Grijalva, V.; Dubinett, S.; Wasler, T.C.; Paul, M.K.; Salehi-Rad, R.; et al. Treating the Intestine with Oral ApoA-I Mimetic Tg6F Reduces Tumor Burden in Mouse Models of Metastatic Lung Cancer. Sci. Rep. 2018, 8, 9032. [CrossRef] [PubMed]

163. Chattopadhyay, A.; Grijalva, V.; Hough, G.; Su, F.; Mukherjee, P.; Farias-Eisner, R.; Anantharamaiah, G.M.; Faull, K.F.; Hwang, L.H.; Navab, M.; et al. Efficacy of tomato concentrates in mouse models of dyslipidemia and cancer. Pharmacol. Res. Perspect. 2015, 3, e00154. [CrossRef] [PubMed]

164. Ungaro, R.; Mehandru, S.; Allen, P.B.; Peyrin-Biroulet, L.; Colombel, J.F. Ulcerative colitis. Lancet 2017, 389, 1756-1770. [CrossRef]

165. Lin, Q.; Lai, R.; Chirieac, L.R.; Li, C.; Thomazy, V.A.; Grammatikakis, I.; Rassidakis, G.Z.; Zhang, W.; Fujio, Y.; Kunisada, K.; et al. Constitutive activation of JAK3/STAT3 in colon carcinoma tumors and cell lines: Inhibition of JAK3/STAT3 signaling induces apoptosis and cell cycle arrest of colon carcinoma cells. Am. J. Pathol. 2005, 167, 969-980. [CrossRef] 
166. Cedo, L.; Reddy, S.T.; Mato, E.; Blanco-Vaca, F.; Escola-Gil, J.C. HDL and LDL: Potential New Players in Breast Cancer Development. J. Clin. Med. 2019, 8, 853. [CrossRef] [PubMed]

167. Borlak, J.; Langer, F.; Chatterji, B. Serum proteome mapping of EGF transgenic mice reveal mechanistic biomarkers of lung cancer precursor lesions with clinical significance for human adenocarcinomas. Biochim. Et Biophys. Acta Mol. Basis Dis. 2018, 1864, 3122-3144. [CrossRef] [PubMed]

168. Chong, P.K.; Lee, H.; Zhou, J.; Liu, S.C.; Loh, M.C.; So, J.B.; Lim, K.H.; Yeoh, K.G.; Lim, Y.P. Reduced plasma APOA1 level is associated with gastric tumor growth in MKN45 mouse xenograft model. J. Proteom. 2010, 73, 1632-1640. [CrossRef] [PubMed]

169. Lozano-Pope, I.; Sharma, A.; Matthias, M.; Doran, K.S.; Obonyo, M. Effect of myeloid differentiation primary response gene 88 on expression profiles of genes during the development and progression of Helicobacter-induced gastric cancer. BMC Cancer 2017, 17, 133. [CrossRef]

170. Takaishi, S.; Wang, T.C. Gene expression profiling in a mouse model of Helicobacter-induced gastric cancer. Cancer Sci. 2007, 98, 284-293. [CrossRef]

171. Hanahan, D.; Weinberg, R.A. Hallmarks of cancer: The next generation. Cell 2011, 144, 646-674. [CrossRef] [PubMed]

172. Dapito, D.H.; Mencin, A.; Gwak, G.Y.; Pradere, J.P.; Jang, M.K.; Mederacke, I.; Caviglia, J.M.; Khiabanian, H.; Adeyemi, A.; Bataller, R.; et al. Promotion of hepatocellular carcinoma by the intestinal microbiota and TLR4. Cancer Cell 2012, 21, 504-516. [CrossRef] [PubMed]

173. Terzic, J.; Grivennikov, S.; Karin, E.; Karin, M. Inflammation and colon cancer. Gastroenterology 2010, 138, 2101-2114. [CrossRef] [PubMed]

174. Fukata, M.; Chen, A.; Vamadevan, A.S.; Cohen, J.; Breglio, K.; Krishnareddy, S.; Hsu, D.; Xu, R.; Harpaz, N.; Dannenberg, A.J.; et al. Toll-like receptor-4 promotes the development of colitis-associated colorectal tumors. Gastroenterology 2007, 133, 1869-1881. [CrossRef] [PubMed]

175. Mineo, C.; Shaul, P.W. Novel biological functions of high-density lipoprotein cholesterol. Circ. Res. 2012, 111, 1079-1090. [CrossRef] [PubMed]

176. Tall, A.R.; Yvan-Charvet, L. Cholesterol, inflammation and innate immunity. Nat. Rev. Immunol. 2015, 15, 104-116. [CrossRef] [PubMed]

177. Tang, C.; Liu, Y.; Kessler, P.S.; Vaughan, A.M.; Oram, J.F. The macrophage cholesterol exporter ABCA1 functions as an anti-inflammatory receptor. J. Biol. Chem. 2009, 284, 32336-32343. [CrossRef] [PubMed]

178. Chen, D.S.; Mellman, I. Oncology meets immunology: The cancer-immunity cycle. Immunity 2013, 39, 1-10. [CrossRef] [PubMed]

179. Schreiber, R.D.; Old, L.J.; Smyth, M.J. Cancer immunoediting: Integrating immunity's roles in cancer suppression and promotion. Sci. 2011, 331, 1565-1570. [CrossRef] [PubMed]

180. Gabrilovich, D.I.; Nagaraj, S. Myeloid-derived suppressor cells as regulators of the immune system. Nat. Rev. Immunol. 2009, 9, 162-174. [CrossRef] [PubMed]

181. Sag, D.; Cekic, C.; Wu, R.; Linden, J.; Hedrick, C.C. The cholesterol transporter ABCG1 links cholesterol homeostasis and tumour immunity. Nat. Commun. 2015, 6, 6354. [CrossRef] [PubMed]

182. Zamanian-Daryoush, M.; Lindner, D.J.; DiDonato, J.A.; Wagner, M.; Buffa, J.; Rayman, P.; Parks, J.S.; Westerterp, M.; Tall, A.R.; Hazen, S.L. Myeloid-specific genetic ablation of ATP-binding cassette transporter ABCA1 is protective against cancer. Oncotarget 2017, 8, 71965-71980. [CrossRef] [PubMed]

183. Degoma, E.M.; Rader, D.J. Novel HDL-directed pharmacotherapeutic strategies. Nat. Rev. Cardiol. 2011, 8, 266-277. [CrossRef] [PubMed]

184. Bradley, M.N.; Hong, C.; Chen, M.; Joseph, S.B.; Wilpitz, D.C.; Wang, X.; Lusis, A.J.; Collins, A.; Hseuh, W.A.; Collins, J.L.; et al. Ligand activation of LXR beta reverses atherosclerosis and cellular cholesterol overload in mice lacking LXR alpha and apoE. J. Clin. Investig. 2007, 117, 2337-2346. [CrossRef] [PubMed]

185. Goodman, K.B.; Bury, M.J.; Cheung, M.; Cichy-Knight, M.A.; Dowdell, S.E.; Dunn, A.K.; Lee, D.; Lieby, J.A.; Moore, M.L.; Scherzer, D.A.; et al. Discovery of potent, selective sulfonylfuran urea endothelial lipase inhibitors. Bioorg. Med. Chem. Lett. 2009, 19, 27-30. [CrossRef] [PubMed]

186. Hoeg, J.M.; Santamarina-Fojo, S.; Berard, A.M.; Cornhill, J.F.; Herderick, E.E.; Feldman, S.H.; Haudenschild, C.C.; Vaisman, B.L.; Hoyt, R.F., Jr.; Demosky, S.J., Jr.; et al. Overexpression of lecithin:cholesterol acyltransferase in transgenic rabbits prevents diet-induced atherosclerosis. Proc. Natl. Acad. Sci. USA 1996, 93, 11448-11453. [CrossRef] [PubMed] 
187. Okamoto, H.; Yonemori, F.; Wakitani, K.; Minowa, T.; Maeda, K.; Shinkai, H. A cholesteryl ester transfer protein inhibitor attenuates atherosclerosis in rabbits. Nature 2000, 406, 203-207. [CrossRef] [PubMed]

188. Nissen, S.E.; Tsunoda, T.; Tuzcu, E.M.; Schoenhagen, P.; Cooper, C.J.; Yasin, M.; Eaton, G.M.; Lauer, M.A.; Sheldon, W.S.; Grines, C.L.; et al. Effect of recombinant ApoA-I Milano on coronary atherosclerosis in patients with acute coronary syndromes: A randomized controlled trial. J. Am. Med. Assoc. 2003, 290, 2292-2300. [CrossRef] [PubMed]

189. Waksman, R.; Torguson, R.; Kent, K.M.; Pichard, A.D.; Suddath, W.O.; Satler, L.F.; Martin, B.D.; Perlman, T.J.; Maltais, J.A.; Weissman, N.J.; et al. A first-in-man, randomized, placebo-controlled study to evaluate the safety and feasibility of autologous delipidated high-density lipoprotein plasma infusions in patients with acute coronary syndrome. J. Am. Coll. Cardiol. 2010, 55, 2727-2735. [CrossRef]

190. Navab, M.; Anantharamaiah, G.M.; Reddy, S.T.; Fogelman, A.M. Apolipoprotein A-I mimetic peptides and their role in atherosclerosis prevention. Nat. Clin. Pract. Cardiovasc. Med. 2006, 3, 540-547. [CrossRef]

191. Chattopadhyay, A.; Navab, M.; Hough, G.; Gao, F.; Meriwether, D.; Grijalva, V.; Springstead, J.R.; Palgnachari, M.N.; Namiri-Kalantari, R.; Su, F.; et al. A novel approach to oral apoA-I mimetic therapy. J. Lipid Res. 2013, 54, 995-1010. [CrossRef] [PubMed]

192. Getz, G.S.; Reardon, C.A. The structure/function of apoprotein A-I mimetic peptides: An update. Curr. Opin. Endocrinol. Diabetesand Obes. 2014, 21, 129-133. [CrossRef] [PubMed]

193. Ditiatkovski, M.; D’Souza, W.; Kesani, R.; Chin-Dusting, J.; De Haan, J.B.; Remaley, A.; Sviridov, D. An apolipoprotein A-I mimetic peptide designed with a reductionist approach stimulates reverse cholesterol transport and reduces atherosclerosis in mice. PLoS ONE 2013, 8, e68802. [CrossRef] [PubMed]

194. Karalis, I.; Jukema, J.W. HDL Mimetics Infusion and Regression of Atherosclerosis: Is It Still Considered a Valid Therapeutic Option? Curr. Cardiol. Rep. 2018, 20, 66. [CrossRef] [PubMed]

195. Shalapour, S.; Lin, X.J.; Bastian, I.N.; Brain, J.; Burt, A.D.; Aksenov, A.A.; Vrbanac, A.F.; Li, W.; Perkins, A.; Matsutani, T.; et al. Inflammation-induced IgA+ cells dismantle anti-liver cancer immunity. Nature 2017, 551, 340-345. [CrossRef] [PubMed]

196. Jia, D.; Lu, M.; Jung, K.H.; Park, J.H.; Yu, L.; Onuchic, J.N.; Kaipparettu, B.A.; Levine, H. Elucidating cancer metabolic plasticity by coupling gene regulation with metabolic pathways. Proc. Natl. Acad. Sci. USA 2019, 116, 3909-3918. [CrossRef] [PubMed]

197. Korolainen, M.A.; Nyman, T.A.; Nyyssonen, P.; Hartikainen, E.S.; Pirttila, T. Multiplexed proteomic analysis of oxidation and concentrations of cerebrospinal fluid proteins in Alzheimer disease. Clin. Chem. 2007, 53, 657-665. [CrossRef] [PubMed]

198. Revilla, G.; Corcoy, R.; Moral, A.; Escola-Gil, J.C.; Mato, E. Cross-Talk between Inflammatory Mediators and the Epithelial Mesenchymal Transition Process in the Development of Thyroid Carcinoma. Int. J. Mol. Sci. 2019, 20, 2466. [CrossRef] [PubMed]

199. Zhao, W.; Prijic, S.; Urban, B.C.; Tisza, M.J.; Zuo, Y.; Li, L.; Tan, Z.; Chen, X.; Mani, S.A.; Chang, J.T. Candidate Antimetastasis Drugs Suppress the Metastatic Capacity of Breast Cancer Cells by Reducing Membrane Fluidity. Cancer Res. 2016, 76, 2037-2049. [CrossRef] [PubMed]

200. Idzko, M.; Ferrari, D.; Eltzschig, H.K. Nucleotide signalling during inflammation. Nature 2014, 509, $310-317$. [CrossRef] [PubMed]

201. Sharma, M.; Tuaine, J.; McLaren, B.; Waters, D.L.; Black, K.; Jones, L.M.; McCormick, S.P. Chemotherapy Agents Alter Plasma Lipids in Breast Cancer Patients and Show Differential Effects on Lipid Metabolism Genes in Liver Cells. PLoS ONE 2016, 11, e0148049. [CrossRef] [PubMed]

202. Feingold, K.R.; Grunfeld, C. The role of HDL in innate immunity. J. Lipid Res. 2011, 52, 1-3. [CrossRef] [PubMed]

(C) 2019 by the authors. Licensee MDPI, Basel, Switzerland. This article is an open access article distributed under the terms and conditions of the Creative Commons Attribution (CC BY) license (http://creativecommons.org/licenses/by/4.0/). 